\title{
Post-COVID-19 syndrome in outpatients: a cohort study
}

Florian Desgranges ${ }^{1}$, Eliana Tadini ${ }^{1}$, Aline Munting ${ }^{1}$, Jean Regina ${ }^{1}$, Paraskevas Filippidis ${ }^{1}$, Benjamin Viala ${ }^{1}$, Eleftherios Karachalias ${ }^{2}$, Véronique Suttels ${ }^{1}$, David Haefliger ${ }^{1}$, Eleftheria Kampouri ${ }^{1,3}$, Mathias Van Singer ${ }^{1}$, Jonathan Tschopp ${ }^{1}$, Laurence Rochat Stettler ${ }^{1}$, Siméon Schaad $^{1}$, Thomas Brahier ${ }^{1}$, Olivier Hugli ${ }^{4}$, Yolanda Mueller Chabloz ${ }^{5}$, Alexandre Gouveia ${ }^{5}$, Onya Opota ${ }^{6}$, Pierre-Nicolas Carron ${ }^{4}$, Benoît Guery ${ }^{1}$, Matthaios Papadimitriou-Olivgeris ${ }^{1 *}$, Noémie Boillat-Blanco ${ }^{1 *}$, the RegCOVID research group.

* Equal contribution to this work

Members of the RegCOVID group are listed in the acknowledgement section.

${ }^{1}$ Infectious Diseases Service, Lausanne University Hospital and University of Lausanne, Switzerland; ${ }^{2}$ Data Scientist, Cardiff, United Kingdom; ${ }^{3}$ Service of Hospital Preventive Medicine, Lausanne University Hospital and University of Lausanne, Switzerland; ${ }^{4}$ Emergency Department, University Hospital of Lausanne and Lausanne University, Switzerland; ${ }^{5}$ Department of Family Medicine, Center for Primary Care and Public Health (Unisanté), University of Lausanne, Switzerland; ${ }^{6}$ Institute of Microbiology, Lausanne University and University Hospital of Lausanne, Switzerland

Keywords: post-acute COVID-19 syndrome, post-COVID-19 syndrome, obesity

Running title: Characteristics of post-COVID-19 syndrome in outpatients

\section{Counts}

- References: 31

- Tables: 3 
medRxiv preprint doi: https://doi.org/10.1101/2021.04.19.21255742; this version posted November 6, 2021. The copyright holder for this preprint (which was not certified by peer review) is the author/funder, who has granted medRxiv a license to display the preprint in perpetuity.

All rights reserved. No reuse allowed without permission.

- Figures: 3

- Appendices: 5 tables

- Article's text: 3171 words

- Abstract: 309 words

\section{Corresponding author}

Dr. Florian Desgranges

Service des maladies infectieuses, Centre hospitalier universitaire vaudois (CHUV)

Rue du Bugnon 46, CH-1011 Lausanne, Switzerland

florian.desranges@chuv.ch; 0041795561721 


\section{ABSTRACT}

\section{Background}

After mild COVID-19, some outpatients experience persistent symptoms. However, data are scarce and prospective studies are urgently needed.

\section{Objectives}

To characterize the post-COVID-19 syndrome after mild COVID-19 and identify predictors.

\section{Participants}

Outpatients with symptoms suggestive of COVID-19 with (1) PCR-confirmed COVID-19 (COVID-positive) or (2) SARS-CoV-2 negative PCR (COVID-negative).

\section{Design}

Monocentric cohort study with prospective phone interview between more than three months to ten months after initial visit to the emergency department and outpatient clinics.

\section{Main Measures}

Data of the initial visits were extracted from the electronic medical file. Predefined persistent symptoms were assessed through a structured phone interview. Associations between longterm symptoms and PCR results, as well as predictors of persistent symptoms among COVIDpositive, were evaluated by multivariate logistic regression adjusted for age, gender, smoking, comorbidities, and timing of the survey.

\section{Key results}

The study population consisted of 418 COVID-positive and 89 COVID-negative patients, mostly young adults (median age of 41 versus 36 years in COVID-positive and COVIDnegative, respectively; $p=0.020)$ and health care workers (67\% versus $82 \% ; p=0.006)$. Median time between the initial visit and the phone survey was 150 days in COVID-positive and 242 days in COVID-negative patients. Persistent symptoms were reported by 223 (53\%) COVID-positive and 33 (37\%) COVID-negative patients $(p=0.006)$. Overall, $21 \%$ COVID- 
positive and 15\% COVID-negative patients $(p=0.182)$ attended care for this purpose. Four surveyed symptoms were independently associated with COVID-19: fatigue (adjusted odds ratio [or] 2.14, 95\%CI 1.04-4.41), smell/taste disorder $(26.5,3.46-202)$, dyspnea $(2.81,1.10$ 7.16) and memory impairment (5.71, 1.53-21.3). Among COVID-positive, female gender $(1.67,1.09-2.56)$ and overweight/obesity $(1.67,1.10-2.56)$ were predictors of persistent symptoms.

\section{Conclusions}

More than half of COVID-positive outpatients report persistent symptoms up to ten months after a mild disease. Only 4 of 14 symptoms were associated with COVID-19 status. The symptoms and predictors of the post-COVID-19 syndrome need further characterization as this condition places a significant burden on society. 


\section{INTRODUCTION}

Almost two years after the first cases of Coronavirus disease 2019 (COVID-19) (1), the severe acute respiratory syndrome coronavirus 2 (SARS-CoV-2) pandemic remains a constant challenge for healthcare systems and affects the well-being of many individuals. The clinical presentation and outcomes of acute COVID-19 are well described. Most patients have mild disease and only a minority need hospital admission (2). In most cases, patients experience a complete resolution of their symptoms after two to six weeks (3), but a subgroup present long lasting symptoms. These persistent symptoms have been described in observational studies $(4,5)$ and cohorts with a large proportion of outpatients $(6,7)$. Three studies reported that an important number of patients had persistent symptoms for more than six months after COVID-19: one study included adults discharged from hospital (8) and two studies focused on outpatients with mild-to-moderate disease $(9,10)$. NICE guideline currently defines postCOVID-19 syndrome as the persistence of signs and symptoms for more than three months after infection, in the absence of an alternative diagnosis (11).

To the best of our knowledge, no study evaluated the prevalence of persistent symptoms among patients with symptoms suggestive of COVID-19, comparing patients positive for SARS-CoV-2 to those tested negative. Furthermore, no study explored the factors associated with persistent symptoms in COVID-19 outpatients. These data may modify patient's management and influence public health vaccination strategies by identifying additional population groups that should be prioritized.

We aimed to compare the prevalence of symptoms persistent for more than three months between SARS-CoV-2 PCR-confirmed (COVID-positive) and PCR-negative (COVIDnegative) patients in outpatient clinics, and to identify predictors of persistent symptoms in COVID-positive. 


\section{METHODS}

\section{Study design, setting and participants}

This cohort study recruited consecutive PCR-confirmed COVID-19 patients (COVIDpositive) during the initial visit in the emergency department (ED), in the SARS-CoV-2 screening center and in two outpatient clinics of the University of Lausanne, Switzerland, between February $26^{\text {th }}$ and April $27^{\text {th }}, 2020$. During the study period, SARS-CoV-2 testing was restricted to patients with symptoms suggestive of COVID-19 (i.e., symptoms of acute respiratory tract infection, history of fever or sudden loss of smell or taste) (1) with at least one risk factor for severe COVID-19 (i.e., $\geq 65$ years old or presence of a comorbidity such as hypertension, diabetes, cancer, chronic cardiac or respiratory disease, immunosuppression) or (2) working as health care workers (HCW). Validated nucleic acid amplification tests were used and a dedicated trained medical team performed nasopharyngeal swabs (12).

We included a control group of outpatients with a negative nasopharyngeal swab PCR SARSCoV-2 result (COVID-negative). This group was recruited in the same health facilities during the same period with the same screening criteria ( $\geq 1$ risk factor for severe COVID-19 or HCW) as COVID-positive. The only differences between the two groups were the types of symptoms at inclusion. The clinical inclusion criteria of COVID-negative were the presence of cough, dyspnea, or history of fever while criteria of COVID-positive were the presence of any symptom suggestive of COVID-19. This difference is related to the fact that we used the COVID-negative group of a previously described prospective cohort $(13,14)$. The use of this pre-existing cohort also influenced the number of COVID-negative patients included.

We excluded patients who 1) did not have a documented health assessment at the time of the test, 2) were hospitalized for more than 24 hours on the day of initial visit or within the following 30 days, 3) were unable to understand the phone survey due to a language barrier or a cognitive impairment, 4) declined to participate, 5) were not reachable for the phone 
interview after at least two attempts, or 6) had the phone survey less than 3 months after the initial visit by mistake. Patients with a positive SARS-CoV-2 test performed in another location before the initial visit in the study centers were excluded, as we also planned to evaluate the impact of the infection on the healthcare system (i.e., medical consultations for persistent symptoms). Moreover, we excluded COVID-negative patients who declared having a documented (PCR or serology) SARS-CoV-2 infection before the phone follow-up.

\section{Procedures}

We retrospectively extracted data from the patients' electronic medical records: demographics, medical history, initial clinical presentation, and SARS-CoV-2 real-time reverse transcriptase PCR (RT-PCR) cycle thresholds. We prospectively conducted a structured and standardized phone survey more than three months after the initial consultation. We collected information on 1) persistent symptoms at the time of the call, 2) secondary hospital admission within 30 days of the initial consultation, 3) medical consultation for persistent symptoms until the call, and 4) anthropometric data. The survey included 14 pre-defined symptoms: fatigue, muscle weakness, dyspnea, cough, thoracic pain, smell or taste disorder, blurred vision, headache, memory impairment, loss of balance, numbness, nausea, sleep disorder, and hair loss. Dyspnea was further categorized according to New York Heart Association (NYHA) grades (15).

Physicians of the infectious diseases service conducted the phone survey. As they did not have dedicated time to perform these calls, they did not survey all patients at the same time point after the initial consultation. Clinicians called COVID-positive patients randomly. They called COVID-positive patients first. Indeed, we decided to include a group of COVIDnegative patients in a second phase when we realized that a large proportion of COVIDpositive participants had persistent symptoms. To account for the timing of symptoms assessment, we classified COVID-positive patients in three equivalent 2-month periods 
according to the time between SARS-CoV-2 diagnosis (initial consultation) and the phone interview: first period: $>3$ months to 5 months after diagnosis, second period: $>5$ months to 7 months after diagnosis, and third period: > 7 months to 10 months after diagnosis.

All data were entered in the Lausanne University Hospital's electronic database "regCOVID" using the REDCap® platform (Research Electronic Data Capture v8.5.24, Vanderbilt University, Tennessee, USA) (16).

\section{Definitions}

Long-term symptoms were defined as symptoms that appeared or worsened during the acute infection phase, were still present at time of the phone call (i.e., more than three months after the initial consultation) and were not explained by an alternative diagnosis. Smell or taste disorder included partial or complete loss of that sense. Numbness included hypoesthesia and paresthesia.

\section{Statistical analyses}

Demographics, clinical features at the time of initial consultation, consultation for persistent symptoms, and prevalence of long-term symptoms (any symptom or individualized symptoms) were compared between COVID-positive and COVID-negative by Mann Whitney-U, chi-squared, or Fisher tests as appropriate, as well as between COVID-positive patients surveyed during the three different periods after SARS-CoV-2 diagnosis by 1-way ANOVA, Kruskal-Wallis, or Chi-squared as appropriate. A $p$ value $<0.05$ was considered statistically significant. The association between COVID-19 and long-term symptoms was evaluated by multivariate logistic regression including potential confounders (age, gender, smoking habits, comorbidities, period of the phone survey). To account for the difference in the timing of symptoms assessment between COVID-positive and COVID-negative, we added a subgroup analysis including COVID-positive and COVID-negative patients surveyed during the same period (the third period). The independent association between the previously 
mentioned factors and each long-term symptom in COVID-positive was evaluated by multivariate logistic regression including the same potential confounders. To account for the large number of HCW in the study population, we added a subgroup analysis including only HCW. STATA (version 15.1, Stata Corp, College Station, TX, USA) statistical software and GraphPad Prism 8.3 (GraphPad, San Diego, CA, USA) were used for analyses.

\section{Ethics}

The project was approved by the Ethics Committee of the Canton of Vaud, Switzerland. All participants gave their verbal consent to participate in this study during the phone interview (project-ID CER-VD 2020-01107 and 2019-02283).

\section{RESULTS}

A total of 956 symptomatic patients had a RT-PCR-confirmed COVID-19 between February $26^{\text {th }}$ and April $27^{\text {th }}, 2020$ and 538 patients were excluded (Figure 1). The remaining 418 (44\%) COVID-positive patients were included in the analysis. 131 symptomatic COVIDnegative patients with a negative SARS-CoV-2 RT-PCR between March $31^{\text {st }}$ and April $26^{\text {th }}$, 2020 were included. 19 patients with a positive SARS-CoV-2 test (RT-PCR or serology) between the initial visit and the phone survey, 17 who could not be reached, 3 who refused to participate, 2 who did not speak one of the investigators' languages and 1 who died were excluded. The remaining 89 (68\%) COVID-negative patients were included in the analysis.

\section{Demographics and clinical presentation}

In both groups, there was a majority of women and $\mathrm{HCW}$. Approximately a third of patients had a comorbidity, mainly obesity, arterial hypertension, and asthma (Table 1). Most patients were tested within the first week of symptom onset and most had normal vital signs at initial consultation. Compared to COVID-negative, COVID-positive were slightly older and less often HCW, active smokers, or asthmatic. COVID-positive reported less often a history of fever, dyspnea, or sore throat at the time of evaluation. 
The study team assessed long-term symptoms via the phone survey at a median of 150 days (interquartile range [IQR], 121-204 days) and 242 days (IQR 236-248 days) after the initial consultation in the COVID-positive and COVID-negative groups, respectively $(p<0.001)$. The study team called 190 (45\%) COVID-positive during the first period (>3 to 5 months after the initial visit), 102 (24\%) during the second period (>5 to 7 months) and 126 (30\%) during the third period ( $>7$ to 10 months). Patients called in the first period were significantly older, less often $\mathrm{HCW}$, and had more comorbidities than those surveyed during the two other periods (Appendix table 1). The study team called all COVID-negative during the third period.

\section{Persistent symptoms}

At the time of the phone survey, 223/418 (53\%) COVID-positive and 33/89 (37\%) COVIDnegative patients $(p=0.006)$ reported the presence of any long-term symptom (Figure $2 \mathrm{~A}$, Table 2).

In COVID-positive, the main reported symptoms were fatigue $(n=132,32 \%)$, smell or taste disorder $(n=93,22 \%)$, dyspnea $(n=66,16 \%)$, headache $(n=50,12 \%)$, memory impairment $(n=48,11 \%)$, hair loss $(n=43,10 \%)$, and sleep disorders $(n=41,10 \%)$, irrespective of HCW status (Appendix table 3B). The prevalence of long-term symptoms was similar during the three time periods (Figure 2B). In COVID-negative, the main reported symptoms were fatigue $(n=15,17 \%)$, headache $(n=10,11 \%)$, sleep disorders $(n=10,11 \%)$, and dyspnea $(n=7,8 \%)$.

COVID-positive reported more often smell or taste disorder $(p=0.001)$, fatigue $(p=0.006)$, and memory impairment $(p=0.003)$ compared to COVID-negative, irrespective of the timing of the survey (Appendix table 2). The prevalence of other symptoms was similar between COVID-positive and COVID-negative. The proportions of patients with $\geq 2$ and $\geq 3$ symptoms were greater in COVID-positive than COVID-negative (38\% vs 19\%; $p=0.001$ and $23 \%$ vs $9.0 \% ; p=0.002$, respectively). The proportion of patients requiring a medical 
consultation for persistent symptoms was similar between COVID-positive and COVIDnegative $(21 \%$ versus $15 \%, p=0.182)$.

\section{Independent association between COVID-positive status and long-term symptoms}

After adjusting for potential confounders, COVID-positive status was a predictor for reporting any symptom (adjusted odds ratio [aOR] 2.04, 95\% CI 1.14-3.67; $p=0.02$ ), fatigue (aOR 2.14, 95\% CI 1.04-4.41; $p=0.04$ ), dyspnea (aOR 2.81, 95\% CI 1.10-7.16; $p=0.03$ ), smell or taste disorder (aOR 26.5, 95\% CI 3.46-202; $\mathrm{p}<0.01)$ and memory impairment (aOR 5.71, 95\% CI $1.53-21.3 ; p=0.01$ ) at the time of the phone survey (Table 2). Of note, dyspnea associated with limited physical activity (NYHA $\geq 2$ ), as well as other long-term symptoms were not associated with COVID status. The results were similar when restricting the analysis to COVID-negative and COVID-positive surveyed during third period (Appendix table 2).

\section{Predictors of long-term symptoms in COVID-positive}

While $57 \%$ of women presented long-term symptoms, only $47 \%$ of men did $(p=0.049)$. While $59 \%$ of overweight/obese patients presented long-term symptoms, only $49 \%$ of patients with healthy weight did $(p=0.041)$. After adjusting for potential confounders, independent predictors of reporting any long-term symptoms were female gender (aOR 1.67, 95\% CI 1.092.56; $p=0.019$ ) and overweight/obesity (aOR 1.67, 95\% CI 1.10-2.56; $p=0.017$; Table 3). The same predictors were associated with long-term fatigue. Overweight/obesity was a predictor of dyspnea. Female gender was a predictor of smell or taste disorder. Active smoking was a predictor of memory impairment (Figure 3). Predictors of other long-term symptoms that were not associated with COVID status are presented in Appendix table 4.

\section{DISCUSSION}

In a large cohort of PCR-confirmed COVID-19 outpatients, we evaluated the prevalence of persistent symptoms 3 to 10 months after diagnosis. We compared COVID-positive to a cohort of patients with negative SARS-CoV-2 PCR with symptoms suggestive of COVID 
during the same period in the same study sites. In these populations consisting mostly of young and healthy participants, most working as $\mathrm{HCW}$, we showed that $53 \%$ of patients with PCR-confirmed COVID-19 report persistent symptoms, while 37\% with negative SARSCoV-2 PCR do. Interestingly, only 4 out of the 14 surveyed persistent symptoms were independently associated with COVID status, i.e., fatigue, smell or taste disorder, dyspnea and memory impairment, irrespective of the timing of the survey.

The type and prevalence of long-lasting symptoms in COVID-positive are consistent with the existing literature. Two studies, evaluating more than 100 laboratory-confirmed COVID-19 outpatients, reported the prevalence of symptoms lasting more than six months after diagnosis: $33-46 \%$ participants with at least one symptom, $14-22 \%$ with fatigue, $8 \%$ with dyspnea, and $14-15 \%$ with change in sense of smell or taste $(9,10)$. The differences between studies may be explained by different selection criteria, data collection methods, and definitions of symptoms.

Strikingly, in our study, the proportion of COVID-positive patients with long-term symptoms was similar between the three surveyed periods. It suggests that symptoms which are present three months after a COVID-19 diagnosis may last for several months. Our findings are supported by a couple of longitudinal studies, which analyzed the evolution of residual symptoms and showed a stable proportion after the acute phase up to seven months $(17,18)$. In our study $23 \%$ of COVID-positive required at least one additional medical visit for COVID-19-related symptoms. These data show the burden on the ambulatory health-care facilities that may be related to the post-COVID-19 syndrome. In contrast with previous findings (19), we did not find a statistical difference in the proportion of patients requiring an additional medical consultation between COVID-positive and COVID-negative, which may be related to the timing of the survey, COVID-negative being surveyed at a later time point. 
Our results shed more light on the association between SARS-CoV-2 infection and long-term symptoms. While some symptoms were more frequent in PCR-confirmed COVID-19 outpatients than in COVID-negative, the prevalence of other symptoms was not different between both groups. Specifically, the prevalence of headache and sleep disorders, two predominant persistent symptoms in COVID-negative patients, was similar between COVIDnegative and COVID-positive. Both symptoms may originate from mixed etiologies including psychosocial factors and/or non-specific post-infectious consequences. The COVID-19 pandemic has greatly impacted our psychosocial behaviors due to confinement, social distancing, masks and changes in working conditions, especially for HCW. Some symptoms may be a consequence of these unprecedented changes (20).

One study evaluating the sequelae in outpatients six months after COVID-19 included a small control group of healthy volunteers and showed that $33 \%$ of COVID-positive outpatients and $5 \%$ of volunteers presented symptoms (9). However, the limited sample size (21 healthy volunteers) and normal health status prevents comparison with our results. Another report also showed that $26 \%$ of seropositive HCW present long-term symptoms eight months after mild COVID, while only $9 \%$ of seronegative do (21). Inclusion of patients irrespective of the presence of symptoms (no or mild prior symptoms) might explain the lower prevalence compared to our results.

Overweight and obesity are increasingly associated with poor outcomes in COVID-19 $(22,23)$ and we found that it was an independent predictor for the presence of any long-term symptom, fatigue, and dyspnea. One study reported an association between body mass index and persistent symptoms after more than 28 days (24). The mechanisms responsible for the post-COVID-19 syndrome are not understood yet and may be multiple $(25,26)$. Long-term symptoms may be due to higher initial organ damages related to a higher infectious burden or a dysregulated inflammatory response. This may be true in people with overweight and 
obesity (27), since the adipose tissue has a high expression of angiotensin-converting enzyme 2 receptors and secretes pro-inflammatory cytokines.

We identified female gender as a predictor for the post-COVID-19 syndrome, in particular for persistent fatigue and smell or taste disorder. Although the results are inconsistent, some studies have described an association between female gender and long-COVID (24), persistent fatigue $(7,8,28)$, post-exertional polypnea (28), and anxiety or depression (8). There may be a difference in the immune response according to the gender, as illustrated by the higher representation of women in autoimmune diseases (29), that may explain divergent findings with COVID-19.

Our study has some limitations. First, most symptoms are subjective and prone to observer bias. Symptoms may also come from an intercurrent condition at the time of COVID-19 diagnosis and not always represent sequelae of SARS-CoV-2 infection. However, inclusion of a symptomatic COVID-negative group supports the association between some persistent symptoms and SARS-CoV-2 infection. Second, inclusion criteria were slightly different between COVID-positive and COVID-negative. COVID-positive presented with any symptom suggestive of COVID-19 (cough, dyspnea, sore throat, history of fever, myalgia, or smell or taste disorders), while the inclusion criteria of COVID-negative patients were the presence of cough, dyspnea or history of fever. However, we do not think that the symptoms difference at first consultation modified our results. Indeed, among COVID-positive patients, $361 / 418(86 \%)$ presented with cough, dyspnea or history of fever, which were the inclusion criteria of the COVID-negative group. Another limitation is related to the timing of the survey, which was performed later in COVID-negative. This difference could lead to an underestimation of the prevalence of persisting symptoms in COVID-negative. However, we added a subgroup analysis restricted to COVID-positive and COVID-negative surveyed during the same period (the third one) and found the same results than in the whole cohort. 
We also observed a difference in the characteristics of COVID-positive surveyed during the first period compared to COVID-positive surveyed during the other two periods. This difference is the result of chance as patients as clinicians called patients randomly. However, we adjusted the multivariate analyses for these characteristics and for the timing of the survey. Our study suffers from a selection bias due to SARS-CoV-2 test criteria (HCW or presence of a risk factor of adverse outcome) at the time of the study, which may prevent generalization of our findings to a broader population. We added a subgroup analysis restricted to HCW and found the same results than in the complete population. This information suggests that our results are generalizable to $\mathrm{HCW}$. Furthermore, we cannot formally exclude that some COVID-negative had an undiagnosed SARS-CoV-2 infection due to a false negative PCR result. However, we used a validated SARS-CoV-2 RT-PCR test on a nasopharyngeal swab performed by a dedicated trained medical team to minimize technical and sample collection bias $(12,30)$.

In conclusion, our study shows that more than half of outpatients with mild-to-moderate COVID-19 report long-term symptoms 3 to 10 months after diagnosis and that $21 \%$ seek medical care for this reason. These data suggest that the post-COVID syndrome places a significant burden on society and especially healthcare systems. There is an urgent need to inform physicians and political authorities about the natural long-term course of COVID-19 in order to plan an appropriate and dedicated management of those with disabling persistent symptoms. 


\section{DECLARATIONS}

\section{Conflict of interest}

The authors have no conflict of interest to declare.

\section{Funding}

This work was supported by an academic award of the Leenaards Foundation (to NBB), the Infectious Disease Service and the emergency department of Lausanne University Hospital. The funding bodies had no role in the design of the study and collection, analysis, and interpretation of data and in writing the manuscript.

\section{Acknowledgements}

We thank all the patients who accepted to participate and make this study possible. We thank all healthcare workers of the triage center and of the emergency department of the University Hospital of Lausanne, who supported the study and managed COVID-19 suspected patients. We thank Nadia Cattaneo and Martin Delaloye who participated to patients' follow-up. We thank Tanguy Espejo and Luca Bosso who included patients in the COVID-negative group.

Members of the RegCOVID group (by alphabetical order): Pierre-Yves Bochud (Committee President), Florian Desgranges, Paraskevas Filippidis, David Haefliger, Eleftheria Evdokia Kampouri, Oriol Manuel (Committee Member), Aline Munting, Jean-Luc Pagani (Committee Member), Matthaios Papadimitriou-Olivgeris (Registry Coordinator and Committee Member), Jean Regina, Laurence Rochat Stettler, Véronique Suttels, Eliana Tadini, Jonathan Tschopp, Mathias Van Singer, Benjamin Viala, Peter Vollenweider (Committee member).

\section{Authors' contributions}

FD, MPO, NBB: study conception, study design, study performance, study management, patients' follow-up, data analysis, data interpretation and manuscript writing.

ET, AM: patients follow-up, data interpretation and manuscript writing. 
JR, PF, BV, NS, DH, EK, MVS, JT, LRS: patients follow-up, data interpretation and critical review of the manuscript.

BG: study design, data interpretation and critical review of the manuscript.

$\mathrm{OH}, \mathrm{YMC}, \mathrm{AG}, \mathrm{PNC}, \mathrm{BG}$ : data interpretation and critical review of the manuscript.

EK: data analysis, interpretation, and critical review of the manuscript.

TB, SS: patients' inclusion, and critical review of the manuscript.

OO: microbiological data interpretation and critical review of the manuscript

MPO had full access to all the data in the study and takes responsibility for the integrity of the data and the accuracy of the data analysis. 


\section{BIBLIOGRAPHY}

1. Zhu N, Zhang D, Wang W, Li X, Yang B, Song J, et al. A Novel Coronavirus from Patients with Pneumonia in China, 2019. N Engl J Med. 2020 Feb 20;382(8):727-33.

2. $\quad \mathrm{Wu} \mathrm{Z}, \mathrm{McGoogan}$ JM. Characteristics of and Important Lessons From the Coronavirus Disease 2019 (COVID-19) Outbreak in China: Summary of a Report of 72314 Cases From the Chinese Center for Disease Control and Prevention. JAMA. 2020 Apr 7;323(13):1239-42.

3. Tenforde MW, Kim SS, Lindsell CJ, Billig Rose E, Shapiro NI, Files DC, et al. Symptom Duration and Risk Factors for Delayed Return to Usual Health Among Outpatients with COVID-19 in a Multistate Health Care Systems Network - United States, March-June 2020. MMWR Morb Mortal Wkly Rep. 2020 Jul 31;69(30):993-8.

4. Carfì A, Bernabei R, Landi F, Gemelli Against COVID-19 Post-Acute Care Study Group. Persistent Symptoms in Patients After Acute COVID-19. JAMA. 2020 Aug 11;324(6):603-5.

5. Garrigues E, Janvier P, Kherabi Y, Le Bot A, Hamon A, Gouze H, et al. Post-discharge persistent symptoms and health-related quality of life after hospitalization for COVID19. Journal of Infection. 2020 Dec;81(6):e4-6.

6. Carvalho-Schneider C, Laurent E, Lemaignen A, Beaufils E, Bourbao-Tournois C, Laribi S, et al. Follow-up of adults with noncritical COVID-19 two months after symptom onset. Clinical Microbiology and Infection. 2021 Feb;27(2):258-63.

7. Townsend L, Dyer AH, Jones K, Dunne J, Mooney A, Gaffney F, et al. Persistent fatigue following SARS-CoV-2 infection is common and independent of severity of initial infection. Madeddu G, editor. PLoS ONE. 2020 Nov 9;15(11):e0240784.

8. Huang C, Huang L, Wang Y, Li X, Ren L, Gu X, et al. 6-month consequences of COVID-19 in patients discharged from hospital: a cohort study. Lancet. 2021 Jan 16;397(10270):220-32.

9. Logue JK, Franko NM, McCulloch DJ, McDonald D, Magedson A, Wolf CR, et al. Sequelae in Adults at 6 Months After COVID-19 Infection. JAMA Netw Open. 2021 Feb 19;4(2):e210830.

10. Klein H, Asseo K, Karni N, Benjamini Y, Nir-Paz R, Muszkat M, et al. Onset, duration and unresolved symptoms, including smell and taste changes, in mild COVID-19 infection: a cohort study in Israeli patients. Clinical Microbiology and Infection. 2021 May 1;27(5):769-74.

11. National Institute for Health and Care Excellence (NICE), the Scottish Intercollegiate Guidelines Network, (SIGN) and the Royal College of General Practitioners (RCGP). COVID-19 rapid guideline: managing the long-term effects of COVID-19. 2020 Dec $18 ; 35$.

12. Opota O, Brouillet R, Greub G, Jaton K. Comparison of SARS-CoV-2 RT-PCR on a high-throughput molecular diagnostic platform and the cobas SARS-CoV-2 test for the diagnostic of COVID-19 on various clinical samples. Pathog Dis. 2020 Nov 11;78(8). 
13. Brahier T, Meuwly J-Y, Pantet O, Brochu Vez M-J, Gerhard Donnet H, Hartley M-A, et al. Lung ultrasonography for risk stratification in patients with COVID-19: a prospective observational cohort study. Clinical Infectious Diseases. 2020 Sep 17;ciaa1408.

14. Schaad S, Brahier T, Hartley M-A, Cordonnier J-B, Bosso L, Espejo T, et al. Point-ofcare lung ultrasonography for early identification of mild COVID-19: a prospective cohort of outpatients in a Swiss screening center. medRxiv. 2021 Mar 26;2021.03.23.21254150.

15. The Criteria Committee of the New York Heart Association . Nomenclature and Criteria for Diagnosis of Diseases of the Heart and Great Vessels. In: 9th ed. Boston, Mass: ed Little, Brown \& Co; 1994. p. 253-6.

16. Harris PA, Taylor R, Minor BL, Elliott V, Fernandez M, O'Neal L, et al. The REDCap consortium: Building an international community of software platform partners. $\mathrm{J}$ Biomed Inform. 2019 Jul;95:103208.

17. Davis HE, Assaf GS, McCorkell L, Wei H, Low RJ, Re'em Y, et al. Characterizing Long COVID in an International Cohort: 7 Months of Symptoms and Their Impact [Internet]. Infectious Diseases (except HIV/AIDS); 2020 Dec [cited 2021 Jan 19]. Available from: http://medrxiv.org/lookup/doi/10.1101/2020.12.24.20248802

18. Nguyen NN, Hoang VT, Lagier J-C, Raoult D, Gautret P. Long-term persistence of olfactory and gustatory disorders in COVID-19 patients. Clinical Microbiology and Infection. 2021 Jan;S1198743X20307813.

19. Lund LC, Hallas J, Nielsen H, Koch A, Mogensen SH, Brun NC, et al. Post-acute effects of SARS-CoV-2 infection in individuals not requiring hospital admission: a Danish population-based cohort study. The Lancet Infectious Diseases. 2021 Oct 1;21(10):1373-82.

20. Alzueta E, Perrin P, Baker FC, Caffarra S, Ramos $\square$ Usuga D, Yuksel D, et al. How the COVID-19 pandemic has changed our lives: A study of psychological correlates across 59 countries. Journal of Clinical Psychology. 2021;77(3):556-70.

21. Havervall S, Rosell A, Phillipson M, Mangsbo SM, Nilsson P, Hober S, et al. Symptoms and Functional Impairment Assessed 8 Months After Mild COVID-19 Among Health Care Workers. JAMA [Internet]. 2021 Apr 7 [cited 2021 Apr 18]; Available from: https://jamanetwork.com/journals/jama/fullarticle/2778528

22. Chu Y, Yang J, Shi J, Zhang P, Wang X. Obesity is associated with increased severity of disease in COVID-19 pneumonia: a systematic review and meta-analysis. European Journal of Medical Research. 2020 Dec 2;25(1):64.

23. Kompaniyets L, Goodman AB, Belay B, Freedman DS, Sucosky MS, Lange SJ, et al. Body Mass Index and Risk for COVID-19-Related Hospitalization, Intensive Care Unit Admission, Invasive Mechanical Ventilation, and Death - United States, MarchDecember 2020. MMWR Morb Mortal Wkly Rep. 2021 Mar 12;70(10):355-61.

24. Sudre CH, Murray B, Varsavsky T, Graham MS, Penfold RS, Bowyer RC, et al. Attributes and predictors of long COVID. Nat Med. 2021 Apr;27(4):626-31. 
medRxiv preprint doi: https://doi.org/10.1101/2021.04.19.21255742; this version posted November 6, 2021. The copyright holder for this preprint (which was not certified by peer review) is the author/funder, who has granted medRxiv a license to display the preprint in perpetuity.

All rights reserved. No reuse allowed without permission.

25. Gupta A, Madhavan MV, Sehgal K, Nair N, Mahajan S, Sehrawat TS, et al. Extrapulmonary manifestations of COVID-19. Nat Med. 2020/07/12 ed. 2020 Jul;26(7):1017-32.

26. Wang F, Kream RM, Stefano GB. Long-Term Respiratory and Neurological Sequelae of COVID-19. Med Sci Monit. 2020 Nov 1;26:e928996-1-e928996-10.

27. Albashir AAD. The potential impacts of obesity on COVID-19. Clin Med (Lond). 2020 Jul;20(4):e109-13.

28. Xiong Q, Xu M, Li J, Liu Y, Zhang J, Xu Y, et al. Clinical sequelae of COVID-19 survivors in Wuhan, China: a single-centre longitudinal study. Clinical Microbiology and Infection. 2021 Jan 1;27(1):89-95.

29. Ngo ST, Steyn FJ, McCombe PA. Gender differences in autoimmune disease. Front Neuroendocrinol. 2014 Aug;35(3):347-69.

30. Mueller L, Scherz V, Greub G, Jaton K, Opota O. Computer-aided medical microbiology monitoring tool: a strategy to adapt to the SARS-CoV-2 epidemic and that highlights RT-PCR consistency [Internet]. Infectious Diseases (except HIV/AIDS); 2020 Jul [cited $2021 \quad$ Apr 5]. Available from: http://medrxiv.org/lookup/doi/10.1101/2020.07.27.20162123 


\section{FIGURE LEGENDS}

\section{Figure 1: Study flow-chart}

Figure 2: Proportions of patients with long-term symptoms at the time of the phone survey. A) Comparison between COVID-positive (positive SARS-CoV-2 RT-PCR) and COVID-negative (negative SARS-CoV-2 RT-PCR); B) Comparison between COVIDpositive surveyed during three different period: Period 1: $>3$ to 5 months after SARS-CoV-2 diagnosis; Period 2: >5 to 7 months after SARS-CoV-2 diagnosis; Period 3: >7 to 10 months after SARS-CoV-2 diagnosis. Data are shown as proportions (\%) with 95\% confidence intervals.

Figure 3: Factors associated with the presence of selected long-term symptoms (fatigue, smell or taste disorder, dyspnea and memory impairment) during the phone survey in COVID-positive patients.

Selected symptoms are those associated with COVID status.

Multivariable analysis adjusted for age, gender, smoking, overweight/obesity, diabetes, asthma, hypertension, cancer, cardiovascular disease, chronic inflammatory disease, period of the phone survey. Adjusted odds ratio for age indicates the risk of fatigue, smell/taste disorder, dyspnea or memory impairment per 5-year age increase. aOR: adjusted odds ratio; CI: confidence interval. ${ }^{*} \mathrm{p}<0.05$ 


\section{TABLES}

\section{Table 1: Characteristics of patients according to SARS-CoV-2 RT-PCR result (COVID-negative and COVID-positive).}

\begin{tabular}{|c|c|c|c|}
\hline Characteristics & COVID-negative $(\mathrm{N}=89$ ) & COVID-positive (N=418) & $P$ value \\
\hline \multicolumn{4}{|l|}{ Demographics } \\
\hline Age in years & $36(29-47)$ & $41(31-54)$ & 0.020 \\
\hline Female gender & $57(64)$ & $261(62)$ & 0.776 \\
\hline Active smoking & $27(30)$ & $46(11)$ & $<0.001$ \\
\hline Health care worker & $73(82)$ & $281(67)$ & 0.006 \\
\hline $\operatorname{BMI}\left(\mathrm{kg} / \mathrm{m}^{2}\right)$ & $24(22-27)$ & $24(22-28)$ & 0.412 \\
\hline \multicolumn{4}{|l|}{ Comorbidities } \\
\hline Any comorbidity & $32(36)$ & $130(31)$ & 0.372 \\
\hline Arterial Hypertension & $8(9.0)$ & $65(16)$ & 0.109 \\
\hline Diabetes Mellitus & $1(1.1)$ & $22(5.3)$ & 0.098 \\
\hline Cardiovascular Disease & $5(5.6)$ & $10(2.4)$ & 0.157 \\
\hline Asthma & $16(18)$ & $43(10)$ & 0.040 \\
\hline Malignancy (hematological/solid organ) & $0(0.0)$ & $15(3.6)$ & 0.085 \\
\hline Chronic inflammatory disease & $1(1.1)$ & $13(3.1)$ & 0.482 \\
\hline Overweight* or obesity & $36(40)$ & $189(45)$ & 0.411 \\
\hline Obesity & $11(12)$ & $72(17)$ & 0.260 \\
\hline Other comorbidities ${ }^{\dagger}$ & $4(4.5)$ & $12(2.9)$ & 0.500 \\
\hline \multicolumn{4}{|l|}{ Symptoms at initial consultation } \\
\hline Days from symptoms onset & $2.0(2.0-4.0)$ & $3.0(2.0-7.0)$ & 0.088 \\
\hline History of fever & $52(58)$ & $172(41)$ & 0.003 \\
\hline Sore throat & $35(39)$ & $79(19)$ & $<0.001$ \\
\hline Rhinorrhea & $43(48)$ & 205 (49) & 0.901 \\
\hline Smell or taste disorder & $9(10)$ & $73(17)$ & 0.087 \\
\hline Cough & $68(76)$ & $305(73)$ & 0.504 \\
\hline Dyspnea & $49(55)$ & $67(16)$ & $<0.001$ \\
\hline Myalgia/arthralgia & $53(60)$ & $249(60)$ & 0.997 \\
\hline Diarrhea & $19(21)$ & $60(14)$ & 0.099 \\
\hline \multicolumn{4}{|l|}{ Signs at initial consultation } \\
\hline Temperature $\left({ }^{\circ} \mathrm{C}\right)$ & $36.9(36.6-37.3)$ & $37.2(36.7-37.9)$ & $<0.001$ \\
\hline Heart rate (beats/min) & $90(78-98)$ & $86(75-98)$ & 0.168 \\
\hline Respiratory rate (breath/min) & $18(16-20)$ & $17(15-20)$ & 0.419 \\
\hline $\mathrm{SpO}_{2}$ on ambient air () & $97(97-98)$ & $97(96-98)$ & 0.405 \\
\hline \multicolumn{4}{|l|}{ Other measures } \\
\hline SARS-CoV-2 cycle threshold value & -- & $22(18-27)$ & -- \\
\hline Consultation for persistent symptoms & $13(15)$ & $87(21)$ & 0.182 \\
\hline
\end{tabular}

Data are number (\%) of patients or median (interquartile range). Two-sided chi-squared or Fisher tests were performed when comparing proportions, and Mann-Whitney U tests were performed for continuous variables.

*Any comorbidity does not include overweight; ${ }^{\dagger}$ Other comorbidities: 7 Neurological Disease, 5 Chronic Kidney Disease, 4 Chronic Obstructive Pulmonary Disease, 4 Cirrhosis.

Missing data: $1 \mathrm{BMI}, 98$ days from symptoms onset, 39 temperature, 84 heart rate, 310 respiratory rate, $41 \mathrm{SpO} 2$ on ambient air, 7 SARS-CoV-2 cycle threshold value.

BMI: body mass index; SpO2: oxygen saturation; SARS-CoV-2: severe acute respiratory syndrome coronavirus 2; RT-PCR: real time reverse transcriptase polymerase chain reaction. 
Table 2. Association between long-term symptoms (any and individualized symptoms) assessed at the time of phone survey and COVID positive status.

\begin{tabular}{|c|c|c|c|c|c|c|}
\hline \multirow[t]{2}{*}{ Long-term symptoms } & \multirow[t]{2}{*}{$\begin{array}{c}\text { COVID-negative } \\
(\mathrm{n}=89)\end{array}$} & \multirow[t]{2}{*}{$\begin{array}{l}\text { COVID-positive } \\
\qquad(\mathrm{n}=\mathbf{4 1 8})\end{array}$} & \multicolumn{2}{|c|}{ Bivariate analysis* } & \multicolumn{2}{|c|}{$\begin{array}{c}\text { Multivariate } \\
\text { analysis**' }\end{array}$} \\
\hline & & & $\begin{array}{c}\text { OR } \\
(95 \% \mathrm{CI})\end{array}$ & $P$ value & $\begin{array}{c}\text { aOR } \\
(95 \% \mathrm{CI})\end{array}$ & $P$ value \\
\hline Any symptoms & $33(37)$ & $223(53)$ & $\begin{array}{c}1.94 \\
(1.21-3.11)\end{array}$ & 0.006 & $\begin{array}{c}2.04 \\
(1.14-3.67)\end{array}$ & 0.017 \\
\hline Fatigue & $15(17)$ & $132(32)$ & $\begin{array}{c}2.28 \\
(1.26-4.12)\end{array}$ & 0.006 & $\begin{array}{c}2.14 \\
(1.04-4.41)\end{array}$ & 0.039 \\
\hline Muscle weakness & $2(2.2)$ & $8(1.9)$ & $\begin{array}{c}0.85 \\
(0.18-4.07)\end{array}$ & 0.837 & $\begin{array}{c}0.65 \\
(0.08-5.21)\end{array}$ & 0.688 \\
\hline Dyspnea & $7(7.9)$ & $66(16)$ & $\begin{array}{c}2.20 \\
(0.97-4.96)\end{array}$ & 0.059 & $\begin{array}{c}2.81 \\
(1.10-7.16)\end{array}$ & 0.030 \\
\hline Dyspnea NYHA $\geq 2$ & $4(4.5)$ & $30(7.2)$ & $\begin{array}{c}1.64 \\
(0.56-4.79)\end{array}$ & 0.363 & $\begin{array}{c}1.11 \\
(0.29-4.32)\end{array}$ & 0.881 \\
\hline Cough & $3(3.4)$ & $25(6.0)$ & $\begin{array}{c}1.82 \\
(0.54-6.2)\end{array}$ & 0.334 & $\begin{array}{c}1.16 \\
(0.24-5.56)\end{array}$ & 0.849 \\
\hline Thoracic pain & $4(4.5)$ & $21(5.0)$ & $\begin{array}{c}1.12 \\
(0.38-3.36)\end{array}$ & 0.834 & $\begin{array}{c}1.11 \\
(0.27-4.54)\end{array}$ & 0.886 \\
\hline Smell or taste disorder & $1(1.1)$ & $93(22)$ & $\begin{array}{c}25.2 \\
(3.46-183)\end{array}$ & 0.001 & $\begin{array}{c}26.5 \\
(3.46-202)\end{array}$ & 0.002 \\
\hline Blurred vision & $2(2.2)$ & $20(4.8)$ & $\begin{array}{c}2.19 \\
(0.50-9.53)\end{array}$ & 0.298 & $\begin{array}{c}3.17 \\
(0.63-16.0)\end{array}$ & 0.163 \\
\hline Headache & $10(11)$ & $50(12)$ & $\begin{array}{c}1.07 \\
(0.52-2.21)\end{array}$ & 0.847 & $\begin{array}{c}1.27 \\
(0.52-3.09)\end{array}$ & 0.601 \\
\hline Loss of balance & $3(3.4)$ & $12(2.9)$ & $\begin{array}{c}0.85 \\
(0.23-3.07)\end{array}$ & 0.801 & $\begin{array}{c}0.37 \\
(0.05-2.62)\end{array}$ & 0.322 \\
\hline Memory impairment & $3(3.4)$ & $48(11)$ & $\begin{array}{c}3.72 \\
(1.13-12.2)\end{array}$ & 0.003 & $\begin{array}{c}5.71 \\
(1.53-21.3)\end{array}$ & 0.010 \\
\hline Numbness & $1(1.1)$ & $14(3.4)$ & $\begin{array}{c}3.05 \\
(0.40-23.5)\end{array}$ & 0.284 & $\begin{array}{c}1.71 \\
(0.14-20.3)\end{array}$ & 0.670 \\
\hline Nausea & $3(3.4)$ & $11(2.6)$ & $\begin{array}{c}0.77 \\
(0.21-2.84)\end{array}$ & 0.700 & $\begin{array}{c}1.30 \\
(0.24-7.08)\end{array}$ & 0.760 \\
\hline Sleep disorder & $10(11)$ & $41(9.8)$ & $\begin{array}{c}0.86 \\
(0.41-1.79)\end{array}$ & 0.685 & $\begin{array}{c}1.03 \\
(0.42-2.52)\end{array}$ & 0.950 \\
\hline Hair loss & $5(5.6)$ & $43(10)$ & $\begin{array}{c}1.92 \\
(0.74-5.01)\end{array}$ & 0.179 & $\begin{array}{c}1.18 \\
(0.36-3.93)\end{array}$ & 0.783 \\
\hline
\end{tabular}

Data are number (\%) of patients.

*symptoms associated with COVID-positive status. ${ }^{\dagger}$ Analysis adjusted for age, gender, smoking, overweight/obesity, diabetes, asthma, hypertension, cancer, cardiovascular disease, chronic inflammatory disease, timing of the phone survey. OR: odds ratio; aOR: adjusted odds ratio; CI: confidence interval; NYHA: New York Heart Association. 
Table 3. Factors associated with the presence of any long-term symptom during the phone survey in COVID-positive patients.

\begin{tabular}{|c|c|c|c|c|c|c|}
\hline \multirow[t]{2}{*}{ Characteristics } & \multirow[t]{2}{*}{$\begin{array}{l}\text { No symptom } \\
(\mathrm{n}=195)\end{array}$} & \multirow[t]{2}{*}{$\begin{array}{l}\text { Any symptom } \\
\qquad(\mathrm{n}=\mathbf{2 2 3})\end{array}$} & \multicolumn{2}{|c|}{ Bivariate analysis* } & \multicolumn{2}{|c|}{$\begin{array}{c}\text { Multivariate } \\
\text { analysis } * \dagger\end{array}$} \\
\hline & & & $\begin{array}{c}\text { OR } \\
(95 \% \mathrm{CI})\end{array}$ & $\begin{array}{c}P \\
\text { value }\end{array}$ & $\begin{array}{c}\operatorname{aOR}(95 \% \\
\text { CI })\end{array}$ & $\begin{array}{c}P \\
\text { value }\end{array}$ \\
\hline \multicolumn{7}{|l|}{ Demographics } \\
\hline Age in years & $41(30-54)$ & $42(33-54)$ & $\begin{array}{c}1.01 \\
(0.95-1.08)\end{array}$ & 0.702 & $\begin{array}{c}1.02 \\
(0.94-1.10)\end{array}$ & 0.682 \\
\hline Female gender & $112(57)$ & 149 (67) & $\begin{array}{c}1.49 \\
(1.00-2.22)\end{array}$ & 0.049 & $\begin{array}{c}1.67 \\
(1.09-2.56)\end{array}$ & 0.019 \\
\hline Active smoking & $16(8.2)$ & $30(13)$ & $\begin{array}{c}1.74 \\
(0.92-3.30)\end{array}$ & 0.090 & $\begin{array}{c}1.72 \\
(0.89-3.34)\end{array}$ & 0.107 \\
\hline \multicolumn{7}{|l|}{ Comorbidities } \\
\hline Overweight or obesity & $78(40)$ & $112(50)$ & $\begin{array}{c}1.50 \\
(1.02-2.21)\end{array}$ & 0.041 & $\begin{array}{c}1.67 \\
(1.10-2.56)\end{array}$ & 0.017 \\
\hline Diabetes Mellitus & $12(6.2)$ & $10(4.5)$ & $\begin{array}{c}0.72 \\
(0.30-1.70)\end{array}$ & 0.447 & $\begin{array}{c}0.69 \\
(0.28-1.72)\end{array}$ & 0.426 \\
\hline Asthma & $19(9.7)$ & $24(11)$ & $\begin{array}{c}1.12 \\
(0.59-2.11)\end{array}$ & 0.732 & $\begin{array}{c}1.11 \\
(0.58-2.14)\end{array}$ & 0.749 \\
\hline Hypertension & $30(15)$ & $35(16)$ & $\begin{array}{c}1.02 \\
(0.60-1.74)\end{array}$ & 0.930 & $\begin{array}{c}0.96 \\
(0.51-1.81)\end{array}$ & 0.912 \\
\hline Malignancy & $5(2.6)$ & $10(4.5)$ & $\begin{array}{c}1.78 \\
(0.60-5.31)\end{array}$ & 0.298 & $\begin{array}{c}1.63 \\
(0.50-5.30)\end{array}$ & 0.414 \\
\hline Cardiovascular Disease & $5(2.6)$ & $5(2.2)$ & $\begin{array}{c}0.87 \\
(0.25-3.06)\end{array}$ & 0.830 & $\begin{array}{c}1.05 \\
(0.27-4.09)\end{array}$ & 0.948 \\
\hline $\begin{array}{l}\text { Chronic inflammatory } \\
\text { Disease }\end{array}$ & $5(2.6)$ & $8(3.6)$ & $\begin{array}{c}1.41 \\
(0.45-4.40)\end{array}$ & 0.549 & $\begin{array}{c}1.18 \\
(0.35-3.94)\end{array}$ & 0.790 \\
\hline \multicolumn{7}{|l|}{$\begin{array}{l}\text { Timing of phone } \\
\text { survey }\end{array}$} \\
\hline$>3-5$ months & $87(45)$ & $103(46)$ & $\begin{array}{c}1.07 \\
(0.72-1.57)\end{array}$ & 0.747 & $\begin{array}{c}1.06 \\
(0.65-1.73)\end{array}$ & 0.808 \\
\hline$>5-7$ months & $47(24)$ & $55(25)$ & $\begin{array}{c}1.03 \\
(0.66-1.61)\end{array}$ & 0.894 & $\begin{array}{c}1.05 \\
(0.61-1.80)\end{array}$ & 0.856 \\
\hline$>7-10$ months & $61(31)$ & $65(29)$ & $\begin{array}{c}0.90 \\
(0.59-1.37)\end{array}$ & 0.635 & $\begin{array}{c}1.00 \\
\text { (reference) }\end{array}$ & -- \\
\hline
\end{tabular}

Data are number (\%) of patients or median (interquartile range). Odds ratio for age indicates the risk of the presence of any symptom per 5-year age increase.

*symptoms associated with the presence of any long-term symptom. ${ }^{\dagger}$ Analysis adjusted for age, gender, smoking, overweight/obesity, diabetes, asthma, hypertension, cancer, cardiovascular disease, chronic inflammatory disease, period of the phone survey.

Missing data: 1 BMI

OR: odds ratio; aOR: adjusted odds ratio; CI: confidence interval. 


\section{Figure 1}

956 patients with a positive RT-PCR S $\Lambda$ RS-CoV-2 result screened for inclusion

538 had at least one exclusion criteria:
$-\quad 198$ were hospitalized within 30 days of their first visit
-174 were unreachable
$-\quad 99$ were included in another study
-39 declincd to participatc
-10 did not speak investigators' languages
-8 had an incompletc CRF
$-\quad 4$ died before the call
-3 werc beyond study period limits
-2 were unable to consent
-1 had no documented health assessment at the date of test

418 COVID-positive included in the analysis 
medRxiv preprint doi: https://doi.org/10.1101/2021.04.19.21255742; this version posted November 6, 2021. The copyright holder for this preprint (which was not certified by peer review) is the author/funder, who has granted medRxiv a license to display the preprint in perpetuity.

All rights reserved. No reuse allowed without permission.

Figure 2
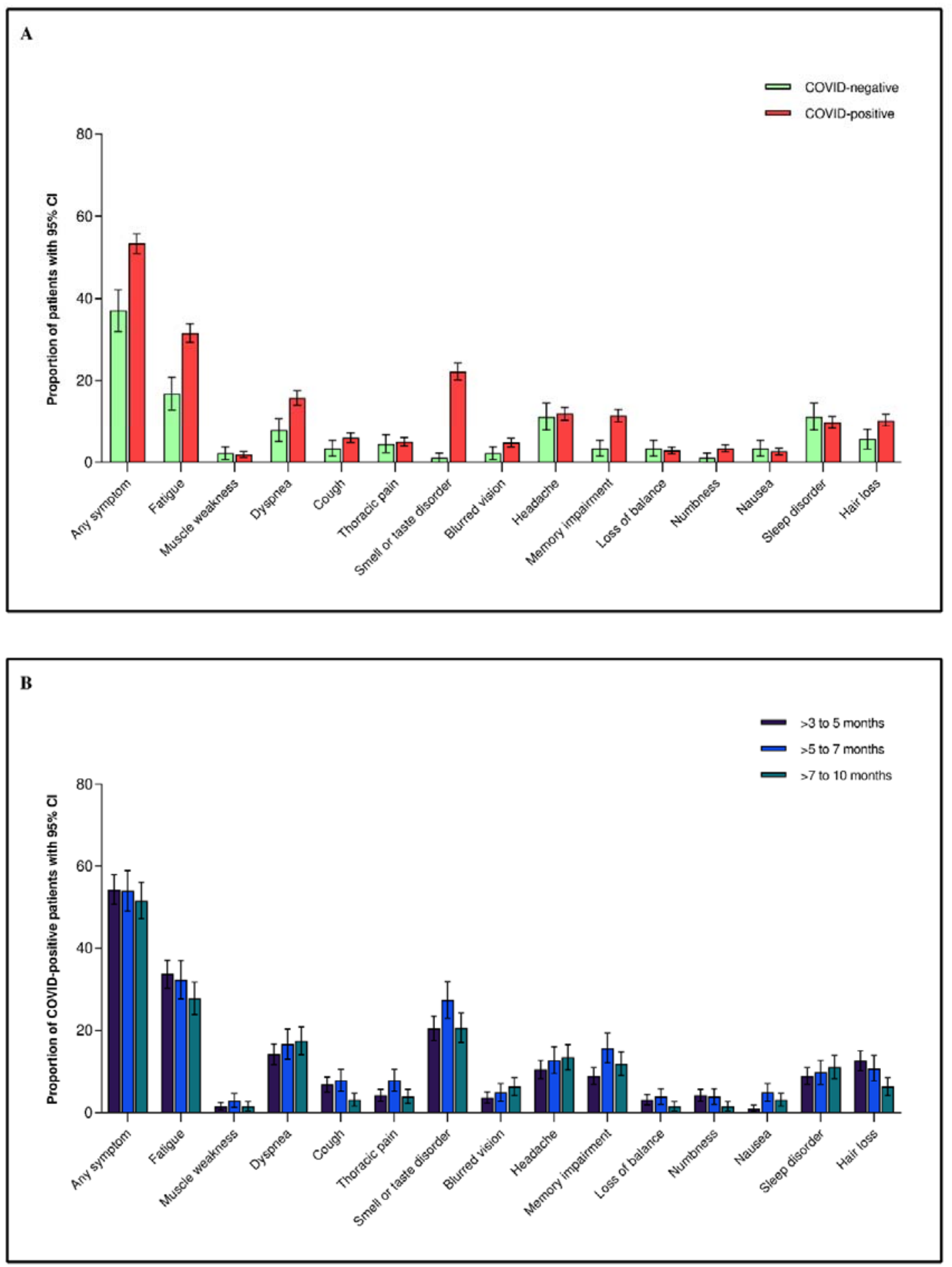
medRxiv preprint doi: https://doi.org/10.1101/2021.04.19.21255742; this version posted November 6, 2021. The copyright holder for this preprint (which was not certified by peer review) is the author/funder, who has granted medRxiv a license to display the preprint in perpetuity.

All rights reserved. No reuse allowed without permission.

Figure 3
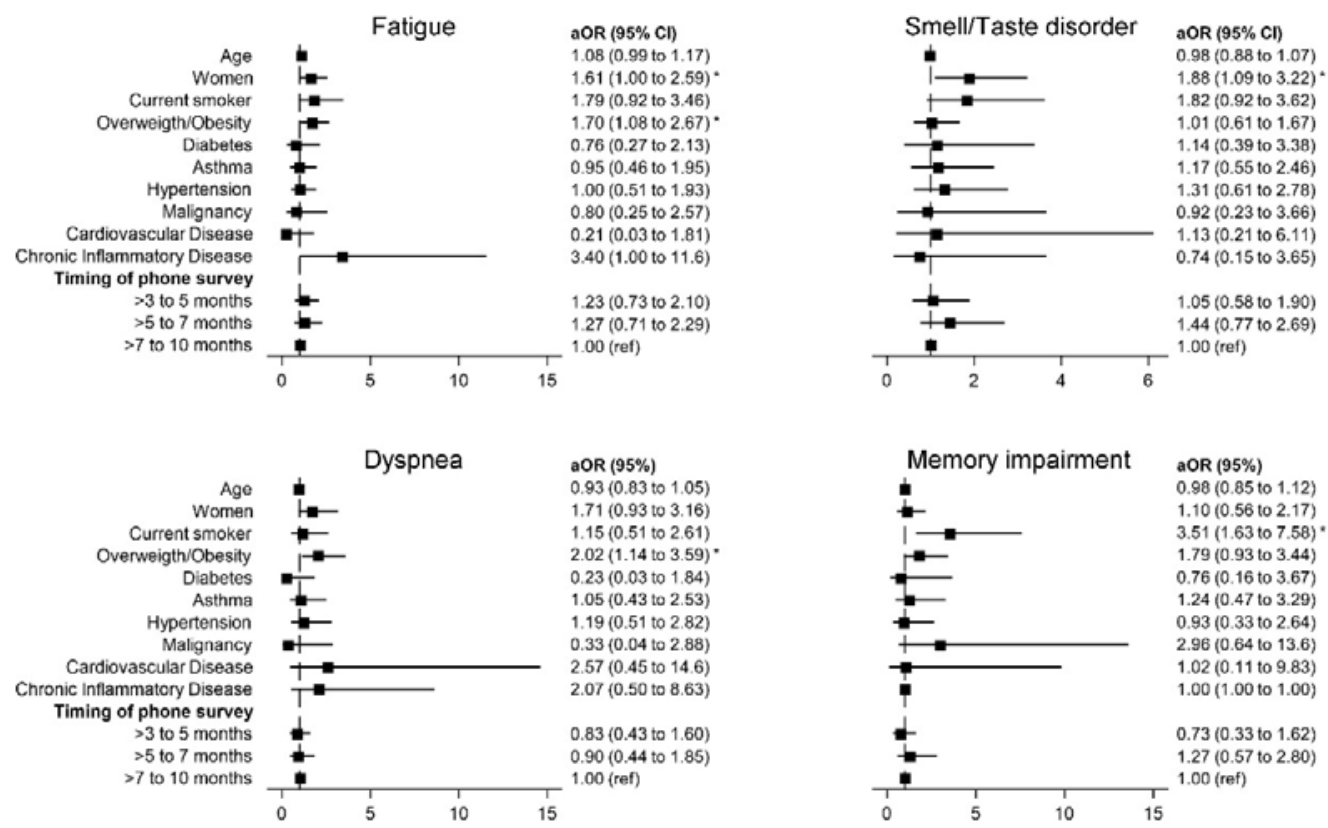


\section{APPENDICES}

Appendix table 1. Characteristics of COVID-positive patients according to the period of the phone interview (time between SARS-CoV-2 diagnosis and phone interview).

\begin{tabular}{|c|c|c|c|c|}
\hline Characteristics & $\begin{array}{l}>3 \text { to } 5 \text { months } \\
\quad(n=190)\end{array}$ & $\begin{array}{l}>5 \text { to } 7 \text { months } \\
\quad(n=102)\end{array}$ & $\begin{array}{l}>7 \text { to } 10 \text { months } \\
\qquad(n=126)\end{array}$ & $P$ value \\
\hline \multicolumn{5}{|l|}{ Demographics } \\
\hline Age (years) & $49(35-60)$ & $35(28-47)$ & $39(29-48)$ & $<0.001$ \\
\hline Female gender & $112(59)$ & $68(67)$ & $81(64)$ & 0.378 \\
\hline Active smoking & $18(9.5)$ & $12(12)$ & $16(13)$ & 0.643 \\
\hline Healthcare workers & $100(53)$ & $74(73)$ & $107(85)$ & $<0.001$ \\
\hline $\operatorname{BMI}\left(\mathrm{kg} / \mathrm{m}^{2}\right)$ & $25(22-29)$ & $24(22-28)$ & $24(22-27)$ & 0.010 \\
\hline \multicolumn{5}{|l|}{ Comorbidities } \\
\hline Any comorbidity & $77(41)$ & $28(27)$ & $25(20)$ & $<0.001$ \\
\hline Arterial Hypertension & $44(23)$ & $8(7.8)$ & $13(10)$ & $<0.001$ \\
\hline Diabetes Mellitus & $15(7.9)$ & $5(4.9)$ & $2(1.6)$ & 0.048 \\
\hline Cardiovascular Disease & $10(5.3)$ & $0(0.0)$ & $1(0.8)$ & 0.002 \\
\hline Asthma & $21(11)$ & $12(12)$ & $10(7.9)$ & 0.572 \\
\hline Malignancy & $10(5.3)$ & $4(3.9)$ & $1(0.8)$ & 0.110 \\
\hline Chronic inflammatory disease & $7(3.7)$ & $2(2.0)$ & $4(3.2)$ & 0.720 \\
\hline Overweight ${ }^{*}$ or obesity & $96(50.5)$ & $46(45.1)$ & $47(37.3)$ & 0.069 \\
\hline Obesity & $43(22.6)$ & $16(15.7)$ & $13(10.3)$ & 0.016 \\
\hline Other comorbidities ${ }^{\dagger}$ & $12(6.3)$ & $0(0.0)$ & $0(0.0)$ & 0.001 \\
\hline \multicolumn{5}{|l|}{ Symptoms at initial consultation } \\
\hline Days from symptoms onset & $4.0(2.0-7.0)$ & $2.0(1.0-4.0)$ & $3.0(2.0-5.0)$ & 0.254 \\
\hline History of fever & $85(45)$ & $32(31)$ & $55(44)$ & 0.069 \\
\hline Sore throat & $33(17)$ & $16(16)$ & $30(24)$ & 0.228 \\
\hline Rhinorrhea & $80(42)$ & $39(38)$ & $86(68)$ & $<0.001$ \\
\hline Smell or taste disorder & $34(18)$ & $22(22)$ & $17(13)$ & 0.273 \\
\hline Cough & $130(68)$ & $77(76)$ & $98(78)$ & 0.150 \\
\hline Dyspnea & $27(14)$ & $17(17)$ & $23(18)$ & 0.618 \\
\hline Myalgia/arthralgia & $113(59)$ & $61(60)$ & $75(60)$ & 0.998 \\
\hline Diarrhea & $28(15)$ & $12(12)$ & $20(16)$ & 0.665 \\
\hline \multicolumn{5}{|l|}{ Signs at initial consultation } \\
\hline Temperature $(\mathrm{C})$ & $37.2(36.7-38.0)$ & $37.2(36.6-37.7)$ & $37.2(36.8-38.0)$ & 0.271 \\
\hline Heart rate (beats/min) & $86(75-97)$ & $88(78-98)$ & $85(75-97)$ & 0.641 \\
\hline Respiratory rate (breath/min) & $17(15-20)$ & $18(16-20)$ & $16(14-18)$ & 0.134 \\
\hline $\mathrm{SpO}_{2}$ on ambient air $(\%)$ & $97(96-98)$ & $97(97-98)$ & $97(97-98)$ & $<0.001$ \\
\hline \multicolumn{5}{|l|}{ Other measures } \\
\hline SARS-CoV-2 cycle threshold value & $21(18-27)$ & $22(18-27)$ & $22(18-27)$ & 0.951 \\
\hline Consultation for persisting symptoms & $51(23)$ & $27(24)$ & $30(23)$ & 0.984 \\
\hline
\end{tabular}

Data are number (\%) of patients or median (interquartile range). Two-sided chi-squared or Fisher tests were performed when comparing proportions, and Mann-Whitney U tests were performed for continuous variables.

${ }^{*}$ Any comorbidity does not include overweight; ${ }^{\dagger}$ comorbidities: 7 Neurological Disease, 3 Chronic Kidney Disease, 2 Chronic Obstructive Pulmonary Disease, 1 Cirrhosis

Missing data: $1 \mathrm{BMI}, 98$ days from symptoms onset, 39 temperature, 84 heart rate, 309 respiratory rate, $41 \mathrm{SpO}_{2}$ on ambient air, 7 SARS-CoV-2 cycle threshold value.

BMI: body mass index; SpO2: oxygen saturation; SARS-CoV-2: severe acute respiratory syndrome coronavirus 2. 
Appendix table 2. Association between long-term symptoms (any and individualized symptoms) assessed at the time of phone survey and COVID-positive status among patients surveyed during the third period.

\begin{tabular}{|c|c|c|c|c|c|c|}
\hline \multirow[b]{2}{*}{ Long-term symptoms } & \multirow{2}{*}{$\begin{array}{c}\text { COVID- } \\
\text { negative } \\
(n=89)\end{array}$} & \multirow{2}{*}{$\begin{array}{l}\text { COVID- } \\
\text { positive } \\
(n=157)\end{array}$} & \multicolumn{2}{|c|}{ Bivariate analysis * } & \multicolumn{2}{|c|}{ Multivariable analysis $*$} \\
\hline & & & $\begin{array}{c}\text { OR } \\
(95 \% \mathrm{CI})\end{array}$ & $P$ value & $\begin{array}{c}\text { aOR } \\
(95 \% \mathrm{CI})\end{array}$ & $P$ value \\
\hline Any symptoms & $33(37 \%)$ & $82(52 \%)$ & $\begin{array}{c}1.86 \\
(1.09-3.16)\end{array}$ & 0.023 & $\begin{array}{c}2.02 \\
(1.11-3.66)\end{array}$ & 0.021 \\
\hline Fatigue & $15(17 \%)$ & $45(29 \%)$ & $\begin{array}{c}1.98 \\
(1.03-3.81)\end{array}$ & 0.040 & $\begin{array}{c}2.16 \\
(1.04-4.51)\end{array}$ & 0.040 \\
\hline Muscle weakness & $2(2.3 \%)$ & $2(1.3 \%)$ & $\begin{array}{c}0.56 \\
(0.08-4.06)\end{array}$ & 0.567 & $\begin{array}{c}0.52 \\
(0.06-4.22)\end{array}$ & 0.541 \\
\hline Dyspnea & $7(7.9 \%)$ & $29(18 \%)$ & $\begin{array}{c}2.65 \\
(1.11-6.34)\end{array}$ & 0.028 & $\begin{array}{c}3.06 \\
(1.15-8.14)\end{array}$ & 0.025 \\
\hline Dyspnea NYHA $\geq 2$ & $4(4.5 \%)$ & $8(5.1 \%)$ & $\begin{array}{c}1.14 \\
(0.33-3.90)\end{array}$ & 0.834 & $\begin{array}{c}1.31 \\
(0.31-5.58)\end{array}$ & 0.716 \\
\hline Cough & $3(3.4 \%)$ & $8(5.1 \%)$ & $\begin{array}{c}1.54 \\
(0.40-5.96)\end{array}$ & 0.532 & $\begin{array}{c}1.74 \\
(0.39-7.74)\end{array}$ & 0.466 \\
\hline Thoracic pain & $4(4.5 \%)$ & $5(3.2 \%)$ & $\begin{array}{c}0.70 \\
(0.18-2.67)\end{array}$ & 0.601 & $\begin{array}{c}1.03 \\
(0.23-4.74)\end{array}$ & 0.966 \\
\hline Smell or taste disorder & $1(1.1 \%)$ & $33(21 \%)$ & $\begin{array}{c}23.4 \\
(3.14-174)\end{array}$ & 0.002 & $\begin{array}{c}26.5 \\
(3.41-206)\end{array}$ & 0.002 \\
\hline Blurred vision & $2(2.3 \%)$ & $11(7.0 \%)$ & $\begin{array}{c}3.28 \\
(0.71-15.1)\end{array}$ & 0.128 & $\begin{array}{c}3.68 \\
(0.72-18.8)\end{array}$ & 0.118 \\
\hline Headache & $10(11 \%)$ & $21(13 \%)$ & $\begin{array}{c}1.22 \\
(0.55-2.72)\end{array}$ & 0.627 & $\begin{array}{c}1.31 \\
(0.53-3.23)\end{array}$ & 0.554 \\
\hline Loss of balance & $3(3.4 \%)$ & $4(2.6 \%)$ & $\begin{array}{c}0.75 \\
(0.16-3.43)\end{array}$ & 0.710 & $\begin{array}{c}0.68 \\
(0.11-4.35)\end{array}$ & 0.688 \\
\hline Memory impairment & $3(3.4 \%)$ & $21(13 \%)$ & $\begin{array}{c}4.43 \\
(1.28-15.3)\end{array}$ & 0.019 & $\begin{array}{c}12.8 \\
(2.49-65.6)\end{array}$ & 0.002 \\
\hline Numbness & $1(1.1 \%)$ & $4(2.6 \%)$ & $\begin{array}{c}2.30 \\
(0.25-20.9)\end{array}$ & 0.459 & $\begin{array}{c}8.08 \\
(0.33-199)\end{array}$ & 0.201 \\
\hline Nausea & $3(3.4 \%)$ & $4(2.6 \%)$ & $\begin{array}{c}0.75 \\
(0.16-3.43)\end{array}$ & 0.710 & $\begin{array}{c}1.12 \\
(0.19-6.55)\end{array}$ & 0.900 \\
\hline Sleep disorder & $10(11 \%)$ & $14(8.9 \%)$ & $\begin{array}{c}0.77 \\
(0.33-1.82)\end{array}$ & 0.557 & $\begin{array}{c}0.85 \\
(0.33-2.24)\end{array}$ & 0.749 \\
\hline Hair loss & $5(5.6 \%)$ & $11(7.0 \%)$ & $\begin{array}{c}1.27 \\
(0.43-3.77)\end{array}$ & 0.672 & $\begin{array}{c}1.42 \\
(0.43-4.67)\end{array}$ & 0.568 \\
\hline
\end{tabular}

Data are number (\%) of patients. *symptoms associated with COVID-positive status. ${ }^{\circ}$ analysis adjusted for age, sex, smoking, overweight/obesity, diabetes, asthma, hypertension, cancer, cardiovascular disease, chronic inflammatory disease. OR: odds ratio; aOR: adjusted odds ratio; CI: confidence interval; NYHA: New York Heart Association. 
Appendix table 3A: Characteristics of COVID-positive patients and proportion of COVIDpositive patients with long-term symptoms (any and individualized symptoms) assessed at the time of phone survey according to health care worker (HCW) status.

\begin{tabular}{|c|c|c|c|}
\hline Characteristics & Not $\mathrm{HCW}(\mathrm{N}=137)$ & $\mathrm{HCW}(\mathrm{N}=281)$ & $P$ value \\
\hline \multicolumn{4}{|l|}{ Demographics } \\
\hline Age in years & $51(38-64)$ & $38(30-48)$ & $<0.001$ \\
\hline Female gender & $66(48)$ & $195(69)$ & $<0.001$ \\
\hline Active smoking & $14(10)$ & $32(11)$ & 0.720 \\
\hline BMI $\left(\mathrm{kg} / \mathrm{m}^{2}\right)$ & $26(23-29)$ & $24(21-28)$ & $<0.001$ \\
\hline \multicolumn{4}{|l|}{ Comorbidities } \\
\hline Any comorbidity & $77(56)$ & $53(19)$ & $<0.001$ \\
\hline Arterial Hypertension & $40(29)$ & $25(8.9)$ & $<0.001$ \\
\hline Diabetes Mellitus & $15(11)$ & $7(2.5)$ & $<0.001$ \\
\hline Cardiovascular Disease & $7(5.1)$ & $3(1.1)$ & 0.017 \\
\hline Asthma & $22(16)$ & $21(7.5)$ & 0.007 \\
\hline Malignancy (hematological/solid organ) & $11(8.0)$ & $4(1.4)$ & 0.001 \\
\hline Chronic inflammatory disease & $8(5.8)$ & $5(1.8)$ & 0.032 \\
\hline Overweight $^{*}$ or obesity & $80(58)$ & $109(39)$ & $<0.001$ \\
\hline Obesity & $31(23)$ & $41(15)$ & 0.041 \\
\hline Other comorbidities $^{\dagger}$ & $9(6.6)$ & $3(1.1)$ & 0.002 \\
\hline \multicolumn{4}{|l|}{ Long-term symptoms } \\
\hline Any symptoms & $76(56)$ & $147(52)$ & 0.543 \\
\hline Fatigue & $45(33)$ & $87(31)$ & 0.737 \\
\hline Muscle weakness & $2(1.5)$ & $6(2.1)$ & 0.636 \\
\hline Dyspnea & $22(16)$ & $44(16)$ & 0.916 \\
\hline Dyspnea NYHA $\geq 2$ & $11(8.0$ & $19(6.8)$ & 0.637 \\
\hline Cough & $11(8.0)$ & $14(5.0)$ & 0.271 \\
\hline Thoracic pain & $9(6.6)$ & $12(4.3)$ & 0.313 \\
\hline Smell or taste disorder & $25(18)$ & $68(24)$ & 0.170 \\
\hline Blurred vision & $7(5.1)$ & $13(4.6)$ & 0.288 \\
\hline Headache & $18(13)$ & $32(11)$ & 0.605 \\
\hline Loss of balance & $7(5.1)$ & $5(1.8)$ & 0.066 \\
\hline Memory impairment & $16(12)$ & $32(11)$ & 0.930 \\
\hline Numbness & $7(5.1)$ & $7(2.5)$ & 0.163 \\
\hline Nausea & $7(5.1)$ & $4(1.4)$ & 0.045 \\
\hline Sleep disorder & $15(11)$ & $26(9.3)$ & 0.584 \\
\hline Hair loss & $14(10)$ & $29(10)$ & 0.974 \\
\hline
\end{tabular}

Data are number (\%) of patients or median (interquartile range). Two-sided chi-squared or Fisher tests were performed when comparing proportions, and Mann-Whitney U tests were performed for continuous variables.

*Any comorbidity does not include overweight; ${ }^{\dagger}$ Other comorbidities: 7 Neurological Disease, 3 Chronic Kidney Disease, 2 Chronic Obstructive Pulmonary Disease, 1 Cirrhosis.

$\mathrm{HCW}$ : health care worker. 
medRxiv preprint doi: https://doi.org/10.1101/2021.04.19.21255742; this version posted November 6, 2021. The copyright holder for this preprint (which was not certified by peer review) is the author/funder, who has granted medRxiv a license to display the preprint in perpetuity.

All rights reserved. No reuse allowed without permission.

Appendix table 3B. Association between long-term symptoms (any and individualized symptoms) assessed at the time of phone survey and COVID-positive status among health care workers.

\begin{tabular}{|c|c|c|c|c|}
\hline \multirow[b]{2}{*}{ Long-term symptoms } & \multirow{2}{*}{$\begin{array}{l}\text { COVID-negative } \\
\qquad(n=73)\end{array}$} & \multirow{2}{*}{$\begin{array}{l}\text { COVID-positive } \\
\qquad(n=281)\end{array}$} & \multicolumn{2}{|c|}{ Multivariable analysis $* \circ$} \\
\hline & & & $\begin{array}{c}\text { aOR } \\
(95 \% \mathrm{CI})\end{array}$ & $P$ value \\
\hline Any symptoms & $29(40 \%)$ & $147(52 \%)$ & $1.95(1.10-3.46)$ & 0.022 \\
\hline Fatigue & $13(18 \%)$ & $87(40 \%)$ & $2.58(1.26-5.32)$ & 0.010 \\
\hline Muscle weakness & $2(2.7 \%)$ & $6(2.1 \%)$ & $0.66(0.11-3.77)$ & 0.637 \\
\hline Dyspnea & $7(9.6 \%)$ & $44(16 \%)$ & $1.87(0.77-4.53)$ & 0.164 \\
\hline Dyspnea NYHA $\geq 2$ & $4(5.5 \%)$ & $19(6.8 \%)$ & $1.18(0.35-3.95)$ & 0.784 \\
\hline Cough & $3(4.1 \%)$ & $14(5 \%)$ & $1.26(0.33-4.78)$ & 0.734 \\
\hline Thoracic pain & $4(5.5 \%)$ & $12(4.3 \%)$ & $0.93(0.27-3.21)$ & 0.911 \\
\hline Smell or taste disorder & $1(1.4 \%)$ & $68(24 \%)$ & $26(3.43-191)$ & 0.002 \\
\hline Blurred vision & $2(2.7 \%)$ & $13(4.6 \%)$ & $1.60(0.33-7.84)$ & 0.564 \\
\hline Headache & $10(14 \%)$ & $32(11 \%)$ & $0.86(0.36-2.02)$ & 0.726 \\
\hline Loss of balance & $3(4.1 \%)$ & $5(1.8 \%)$ & $0.49(0.09-2.57)$ & 0.400 \\
\hline Memory impairment & $3(4.1 \%)$ & $32(11 \%)$ & $4.50(1.24-16)$ & 0.022 \\
\hline Numbness & $1(1.4 \%)$ & $7(2.5 \%)$ & $2.49(0.26-23.56)$ & 0.426 \\
\hline Nausea & $3(4.1 \%)$ & $4(1.4 \%)$ & $0.60(0.09-3.78)$ & 0.582 \\
\hline Sleep disorder & $7(9.6 \%)$ & $26(9.3 \%)$ & $1.22(0.48-3.11)$ & 0.677 \\
\hline Hair loss & $4(5.5 \%)$ & $29(10 \%)$ & $2.09(0.65-6.74)$ & 0.218 \\
\hline
\end{tabular}

Data are number (\%) of patients. *symptoms associated with COVID-positive status. ${ }^{\circ}$ analysis adjusted for age, sex, smoking, overweight/obesity, diabetes, asthma, hypertension, cancer, cardiovascular disease, chronic inflammatory disease. OR: odds ratio; aOR: adjusted odds ratio; CI: confidence interval; NYHA: New York Heart Association. 
Appendix Table 4. Factors associated with the presence of long-term symptoms during the phone survey in COVID-positive patients.

Analysis adjusted for age, gender, smoking, overweight/obesity, diabetes, asthma, hypertension, cancer, cardiovascular disease, chronic inflammatory disease, period of the phone survey.

Missing data: 1 BMI.

Adjusted odds ratio for age indicates the risk of the presence of any symptom or individualized symptoms per 5year age increase.

aOR: adjusted odds ratio; CI: confidence interval.

\begin{tabular}{|c|c|c|c|c|c|c|c|c|}
\hline \multirow[t]{2}{*}{ Predictive factors } & \multicolumn{2}{|l|}{ Dyspnea } & \multicolumn{2}{|l|}{ Cough } & \multicolumn{2}{|c|}{ Thoracic pain } & \multicolumn{2}{|c|}{$\begin{array}{c}\text { Smell or taste } \\
\text { disorder }\end{array}$} \\
\hline & $\begin{array}{c}\text { aOR } \\
(95 \% \mathrm{CI})\end{array}$ & $P$ & $\begin{array}{c}\text { aOR } \\
(95 \% \mathrm{CI})\end{array}$ & $P$ & $\begin{array}{c}\text { aOR } \\
(95 \% \mathrm{CI})\end{array}$ & $P$ & $\begin{array}{c}\text { aOR } \\
(95 \% \mathrm{CI})\end{array}$ & $P$ \\
\hline \multicolumn{9}{|l|}{ Demographics } \\
\hline Age & $\begin{array}{c}0.93 \\
(0.83-1.05)\end{array}$ & 0.26 & $\begin{array}{c}0.91 \\
(0.76-1.10)\end{array}$ & 0.32 & $\begin{array}{c}0.96 \\
(0.80-1.16)\end{array}$ & 0.70 & $\begin{array}{c}0.98 \\
(0.88-1.07)\end{array}$ & 0.61 \\
\hline Female gender & $\begin{array}{c}1.71 \\
(0.93-3.16)\end{array}$ & 0.09 & $\begin{array}{c}2.01 \\
(0.74-5.44)\end{array}$ & 0.17 & $\begin{array}{c}1.28 \\
(0.45-3.61)\end{array}$ & 0.65 & $\begin{array}{c}1.88 \\
(1.09-3.22)\end{array}$ & 0.02 \\
\hline Active smoking & $\begin{array}{c}1.15 \\
(0.51-2.61)\end{array}$ & 0.73 & $\begin{array}{c}3.69 \\
(1.35-10.06)\end{array}$ & 0.01 & $\begin{array}{c}1.09 \\
(0.29-4.12)\end{array}$ & 0.90 & $\begin{array}{c}1.82 \\
(0.92-3.62)\end{array}$ & 0.09 \\
\hline \multicolumn{9}{|l|}{ Comorbidities } \\
\hline Overweight or obesity & $\begin{array}{c}2.02 \\
(1.14-3.59)\end{array}$ & 0.02 & $\begin{array}{c}2.96 \\
(1.19-7.40)\end{array}$ & 0.02 & $\begin{array}{c}0.68 \\
(0.26-1.82)\end{array}$ & 0.44 & $\begin{array}{c}1.01 \\
(0.61-1.67)\end{array}$ & 0.96 \\
\hline Diabetes & $\begin{array}{c}0.23 \\
(0.03-1.84)\end{array}$ & 0.17 & $\begin{array}{c}0.47 \\
(0.05-4.18)\end{array}$ & 0.50 & $\begin{array}{c}1.00 \\
(1.00-1.00)\end{array}$ & - & $\begin{array}{c}1.14 \\
(0.39-3.38)\end{array}$ & 0.81 \\
\hline Asthma & $\begin{array}{c}1.05 \\
(0.43-2.53)\end{array}$ & 0.92 & $\begin{array}{c}0.32 \\
(0.04-2.55)\end{array}$ & 0.28 & $\begin{array}{c}2.65 \\
(0.88-7.96)\end{array}$ & 0.08 & $\begin{array}{c}1.17 \\
(0.55-2.46)\end{array}$ & 0.69 \\
\hline Hypertension & $\begin{array}{c}1.19 \\
(0.51-2.82)\end{array}$ & 0.69 & $\begin{array}{c}1.89 \\
(0.56-6.40)\end{array}$ & 0.31 & $\begin{array}{c}0.37 \\
(0.04-3.29)\end{array}$ & 0.37 & $\begin{array}{c}1.31 \\
(0.61-2.78)\end{array}$ & 0.49 \\
\hline Malignancy & $\begin{array}{c}0.33 \\
(0.04-2.88)\end{array}$ & 0.32 & $\begin{array}{c}1.26 \\
(0.13-12.49)\end{array}$ & 0.84 & $\begin{array}{c}1.42 \\
(0.14-14.69)\end{array}$ & 0.77 & $\begin{array}{c}0.92 \\
(0.23-3.66)\end{array}$ & 0.90 \\
\hline Cardiovascular disease & $\begin{array}{c}2.57 \\
(0.45-14.61)\end{array}$ & 0.29 & $\begin{array}{c}2.33 \\
(0.21-25.58)\end{array}$ & 0.49 & $\begin{array}{c}4.31 \\
(0.35-53.27)\end{array}$ & 0.26 & $\begin{array}{c}1.13 \\
(0.21-6.11)\end{array}$ & 0.89 \\
\hline Chronic inflammatory disease & $\begin{array}{c}2.07 \\
(0.50-8.63)\end{array}$ & 0.32 & $\begin{array}{c}1.00 \\
(1.00-1.00)\end{array}$ & -- & $\begin{array}{c}2.52 \\
(0.25-25.80)\end{array}$ & 0.44 & $\begin{array}{c}0.74 \\
(0.15-3.65)\end{array}$ & 0.71 \\
\hline \multicolumn{9}{|l|}{$\begin{array}{l}\text { Timing of } \\
\text { phone survey }\end{array}$} \\
\hline$>3$ to 5 months & $\begin{array}{c}0.83 \\
(0.43-1.60)\end{array}$ & 0.58 & $\begin{array}{c}2.53 \\
(0.75-8.55)\end{array}$ & 0.14 & $\begin{array}{c}1.17 \\
(0.34-3.99)\end{array}$ & 0.80 & $\begin{array}{c}1.05 \\
(0.58-1.90)\end{array}$ & 0.88 \\
\hline$>5$ to 7 months & $\begin{array}{c}0.90 \\
(0.44-1.85)\end{array}$ & 0.78 & $\begin{array}{c}2.57 \\
(0.71-9.26)\end{array}$ & 0.15 & $\begin{array}{c}2.10 \\
(0.65-6.82)\end{array}$ & 0.22 & $\begin{array}{c}1.44 \\
(0.77-2.69)\end{array}$ & 0.26 \\
\hline$>7$ to 10 months & $\begin{array}{c}1.00 \\
\text { (reference) }\end{array}$ & -- & $\begin{array}{c}1.00 \\
\text { (reference) }\end{array}$ & -- & $\begin{array}{c}1.00 \\
\text { (reference) }\end{array}$ & -- & $\begin{array}{c}1.00 \\
\text { (reference) }\end{array}$ & -- \\
\hline
\end{tabular}




\begin{tabular}{|c|c|c|c|c|c|c|c|c|}
\hline \multirow[t]{2}{*}{ Predictive factors } & \multicolumn{2}{|c|}{$\begin{array}{c}\text { Memory } \\
\text { impairment }\end{array}$} & \multicolumn{2}{|c|}{ Headache } & \multicolumn{2}{|c|}{ Blurred vision } & \multicolumn{2}{|c|}{ Loss of balance } \\
\hline & $\begin{array}{c}\text { aOR } \\
(95 \% \mathrm{CI})\end{array}$ & $\boldsymbol{P}$ & $\begin{array}{c}\text { aOR } \\
(95 \% \mathrm{CI})\end{array}$ & $\boldsymbol{P}$ & $\begin{array}{c}\text { aOR } \\
(95 \% \mathrm{CI})\end{array}$ & $\boldsymbol{P}$ & $\begin{array}{c}\text { aOR } \\
(95 \% \mathrm{CI})\end{array}$ & $P$ \\
\hline \multicolumn{9}{|l|}{ Demographics } \\
\hline Age & $\begin{array}{c}0.98 \\
(0.85-1.12)\end{array}$ & 0.74 & $\begin{array}{c}0.96 \\
(0.85-1.09)\end{array}$ & 0.57 & $\begin{array}{c}1.00 \\
(0.81-1.22)\end{array}$ & 0.97 & $\begin{array}{c}1.30 \\
(1.00-1.68)\end{array}$ & 0.05 \\
\hline Female gender & $\begin{array}{c}1.10 \\
(0.56-2.17)\end{array}$ & 0.77 & $\begin{array}{c}1.11 \\
(0.58-2.13)\end{array}$ & 0.76 & $\begin{array}{c}1.09 \\
(0.41-2.87)\end{array}$ & 0.87 & $\begin{array}{c}2.26 \\
(0.52-9.89)\end{array}$ & 0.28 \\
\hline Active smoking & $\begin{array}{c}3.51 \\
(1.63-7.58)\end{array}$ & 0.00 & $\begin{array}{c}0.62 \\
(0.21-1.84)\end{array}$ & 0.39 & $\begin{array}{c}3.15 \\
(1.02-9.81)\end{array}$ & 0.05 & $\begin{array}{c}3.25 \\
(0.55-19.1)\end{array}$ & 0.19 \\
\hline \multicolumn{9}{|l|}{ Comorbidities } \\
\hline Overweight or obesity & $\begin{array}{c}1.79 \\
(0.93-3.44)\end{array}$ & 0.08 & $\begin{array}{c}0.92 \\
(0.48-1.75)\end{array}$ & 0.79 & $\begin{array}{c}2.11 \\
(0.76-5.84)\end{array}$ & 0.15 & $\begin{array}{c}1.46 \\
(0.35-6.09)\end{array}$ & 0.61 \\
\hline Diabetes & $\begin{array}{c}0.76 \\
(0.16-3.67)\end{array}$ & 0.73 & $\begin{array}{c}1.04 \\
(0.22-4.86)\end{array}$ & 0.96 & $\begin{array}{c}0.72 \\
(0.08-6.37)\end{array}$ & 0.77 & $\begin{array}{c}2.65 \\
(0.42-16.8)\end{array}$ & 0.30 \\
\hline Asthma & $\begin{array}{c}1.24 \\
(0.47-3.29)\end{array}$ & 0.67 & $\begin{array}{c}1.33 \\
(0.52-3.38)\end{array}$ & 0.55 & $\begin{array}{c}0.46 \\
(0.06-3.71)\end{array}$ & 0.47 & $\begin{array}{c}1.00 \\
(1.00-1.00)\end{array}$ & -- \\
\hline Hypertension & $\begin{array}{c}0.93 \\
(0.33-2.64)\end{array}$ & 0.90 & $\begin{array}{c}0.79 \\
(0.28-2.22)\end{array}$ & 0.65 & $\begin{array}{c}2.20 \\
(0.62-7.72)\end{array}$ & 0.22 & $\begin{array}{c}2.23 \\
(0.44-11.2)\end{array}$ & 0.33 \\
\hline Malignancy & $\begin{array}{c}2.96 \\
(0.64-13.6)\end{array}$ & 0.16 & $\begin{array}{c}1.55 \\
(0.36-6.77)\end{array}$ & 0.56 & $\begin{array}{c}1.00 \\
(1.00-1.00)\end{array}$ & -- & $\begin{array}{c}1.00 \\
(1.00-1.00)\end{array}$ & -- \\
\hline Cardiovascular disease & $\begin{array}{c}1.02 \\
(0.11-9.83)\end{array}$ & 0.99 & $\begin{array}{c}1.00 \\
(1.00-1.00)\end{array}$ & -- & $\begin{array}{c}1.00 \\
(1.00-1.00)\end{array}$ & -- & $\begin{array}{c}3.63 \\
(0.26-50.3)\end{array}$ & 0.34 \\
\hline Chronic inflammatory disease & $\begin{array}{c}1.00 \\
(1.00-1.00)\end{array}$ & -- & $\begin{array}{c}3.68 \\
(0.96-14.1)\end{array}$ & 0.06 & $\begin{array}{c}1.58 \\
(0.18-14.2)\end{array}$ & 0.68 & $\begin{array}{c}15.77 \\
(2.09-119)\end{array}$ & 0.01 \\
\hline \multicolumn{9}{|l|}{$\begin{array}{l}\text { Timing of } \\
\text { phone survey }\end{array}$} \\
\hline$>3$ to 5 months & $\begin{array}{c}0.73 \\
(0.33-1.62)\end{array}$ & 0.44 & $\begin{array}{c}0.83 \\
(0.40-1.72)\end{array}$ & 0.61 & $\begin{array}{c}0.57 \\
(0.19-1.72)\end{array}$ & 0.32 & $\begin{array}{c}1.35 \\
(0.21-8.87)\end{array}$ & 0.75 \\
\hline$>5$ to 7 months & $\begin{array}{c}1.27 \\
(0.57-2.80)\end{array}$ & 0.56 & $\begin{array}{c}0.91 \\
(0.41-2.01)\end{array}$ & 0.82 & $\begin{array}{c}0.84 \\
(0.26-2.77)\end{array}$ & 0.78 & $\begin{array}{c}5.18 \\
(0.72-37.1)\end{array}$ & 0.10 \\
\hline$>7$ to 10 months & $\begin{array}{c}1.00 \\
\text { (reference) }\end{array}$ & -- & $\begin{array}{c}1.00 \\
\text { (reference) }\end{array}$ & -- & $\begin{array}{c}1.00 \\
\text { (reference) }\end{array}$ & -- & $\begin{array}{c}1.00 \\
\text { (reference) }\end{array}$ & -- \\
\hline
\end{tabular}


medRxiv preprint doi: https://doi.org/10.1101/2021.04.19.21255742; this version posted November 6, 2021. The copyright holder for this preprint (which was not certified by peer review) is the author/funder, who has granted medRxiv a license to display the preprint in perpetuity.

\begin{tabular}{|c|c|c|c|c|c|c|c|c|}
\hline \multirow[t]{2}{*}{ Predictive factors } & \multicolumn{2}{|c|}{ Numbness } & \multicolumn{2}{|c|}{ Muscle weakness } & \multicolumn{2}{|c|}{ Fatigue } & \multicolumn{2}{|c|}{ Sleep disorder } \\
\hline & $\begin{array}{c}\text { aOR } \\
(95 \% \mathrm{CI})\end{array}$ & $P$ & $\begin{array}{c}\text { aOR } \\
(95 \% \mathrm{CI})\end{array}$ & $P$ & $\begin{array}{c}\text { aOR } \\
(95 \% \mathrm{CI})\end{array}$ & $P$ & $\begin{array}{c}\mathrm{aOR} \\
(95 \% \mathrm{CI})\end{array}$ & $P$ \\
\hline \multicolumn{9}{|l|}{ Demographics } \\
\hline Age & $\begin{array}{c}1.06 \\
(0.85-1.33)\end{array}$ & 0.58 & $\begin{array}{c}1.07 \\
(0.80-1.44)\end{array}$ & 0.65 & $\begin{array}{c}1.08 \\
(0.99-1.17)\end{array}$ & 0.09 & $\begin{array}{c}1.03 \\
(0.90-1.19)\end{array}$ & 0.65 \\
\hline Female gender & $\begin{array}{c}0.69 \\
(0.22-2.17)\end{array}$ & 0.53 & $\begin{array}{c}2.45 \\
(0.42-14.23)\end{array}$ & 0.32 & $\begin{array}{c}1.61 \\
(1.00-2.59)\end{array}$ & 0.05 & $\begin{array}{c}1.32 \\
(0.64-2.71)\end{array}$ & 0.45 \\
\hline Active smoking & $\begin{array}{c}0.63 \\
(0.08-5.19)\end{array}$ & 0.67 & $\begin{array}{c}3.75 \\
(0.65-21.52)\end{array}$ & 0.14 & $\begin{array}{c}1.79 \\
(0.92-3.46)\end{array}$ & 0.09 & $\begin{array}{c}1.83 \\
(0.73-4.59)\end{array}$ & 0.20 \\
\hline \multicolumn{9}{|l|}{ Comorbidities } \\
\hline Overweight or obesity & $\begin{array}{c}2.74 \\
(0.79-9.50)\end{array}$ & 0.11 & $\begin{array}{c}1.19 \\
(0.26-5.47)\end{array}$ & 0.82 & $\begin{array}{c}1.70 \\
(1.08-2.67)\end{array}$ & 0.02 & $\begin{array}{c}2.08 \\
(1.03-4.21)\end{array}$ & 0.04 \\
\hline Diabetes & $\begin{array}{c}1.09 \\
(0.12-10.17)\end{array}$ & 0.94 & $\begin{array}{c}9.89 \\
(1.47-66.36)\end{array}$ & 0.02 & $\begin{array}{c}0.76 \\
(0.27-2.13)\end{array}$ & 0.60 & $\begin{array}{c}1.00 \\
(1.00-1.00)\end{array}$ & - \\
\hline Asthma & $\begin{array}{c}2.78 \\
(0.70-10.99)\end{array}$ & 0.14 & $\begin{array}{c}1.00 \\
(1.00-1.00)\end{array}$ & - & $\begin{array}{c}0.95 \\
(0.46-1.95)\end{array}$ & 0.89 & $\begin{array}{c}0.99 \\
(0.32-3.01)\end{array}$ & 0.98 \\
\hline Hypertension & $\begin{array}{c}0.78 \\
(0.16-3.77)\end{array}$ & 0.76 & $\begin{array}{c}0.49 \\
(0.04-6.44)\end{array}$ & 0.59 & $\begin{array}{c}1.00 \\
(0.51-1.93)\end{array}$ & 0.99 & $\begin{array}{c}1.39 \\
(0.54-3.60)\end{array}$ & 0.50 \\
\hline Malignancy & $\begin{array}{c}1.42 \\
(0.14-14.16)\end{array}$ & 0.76 & $\begin{array}{c}1.00 \\
(1.00-1.00)\end{array}$ & - & $\begin{array}{c}0.80 \\
(0.25-2.57)\end{array}$ & 0.70 & $\begin{array}{c}1.81 \\
(0.42-7.76)\end{array}$ & 0.42 \\
\hline Cardiovascular disease & $\begin{array}{c}1.00 \\
(1.00-1.00)\end{array}$ & - & $\begin{array}{c}1.00 \\
(1.00-1.00)\end{array}$ & - & $\begin{array}{c}0.21 \\
(0.03-1.81)\end{array}$ & 0.16 & $\begin{array}{c}1.00 \\
(1.00-1.00)\end{array}$ & \\
\hline Chronic inflammatory disease & $\begin{array}{c}1.59 \\
(0.16-16.05)\end{array}$ & 0.69 & $\begin{array}{c}1.00 \\
(1.00-1.00)\end{array}$ & - & $\begin{array}{c}3.40 \\
(1.00-11.56)\end{array}$ & 0.05 & $\begin{array}{c}1.82 \\
(0.43-7.69)\end{array}$ & 0.42 \\
\hline \multicolumn{9}{|l|}{$\begin{array}{l}\text { Timing of } \\
\text { phone survey }\end{array}$} \\
\hline$>3$ to 5 months & $\begin{array}{c}2.14 \\
(0.42-10.91)\end{array}$ & 0.36 & $\begin{array}{c}0.89 \\
(0.13-6.14)\end{array}$ & 0.91 & $\begin{array}{c}1.23 \\
(0.73-2.10)\end{array}$ & 0.44 & $\begin{array}{c}0.74 \\
(0.33-1.64)\end{array}$ & 0.46 \\
\hline$>5$ to 7 months & $\begin{array}{c}2.17 \\
(0.38-12.49)\end{array}$ & 0.38 & $\begin{array}{c}1.77 \\
(0.27-11.43)\end{array}$ & 0.55 & $\begin{array}{c}1.27 \\
(0.71-2.29)\end{array}$ & 0.42 & $\begin{array}{c}0.85 \\
(0.35-2.06)\end{array}$ & 0.72 \\
\hline$>7$ to 10 months & $\begin{array}{c}1.00 \\
\text { (reference) }\end{array}$ & -- & $\begin{array}{c}1.00 \\
\text { (reference) }\end{array}$ & -- & $\begin{array}{c}1.00 \\
\text { (reference) }\end{array}$ & -- & $\begin{array}{c}1.00 \\
\text { (reference) }\end{array}$ & -- \\
\hline
\end{tabular}


medRxiv preprint doi: https://doi.org/10.1101/2021.04.19.21255742; this version posted November 6, 2021. The copyright holder for this preprint (which was not certified by peer review) is the author/funder, who has granted medRxiv a license to display the preprint in perpetuity. All rights reserved. No reuse allowed without permission.

\begin{tabular}{|c|c|c|c|c|}
\hline \multirow[t]{2}{*}{ Predictive factors } & \multicolumn{2}{|l|}{ Nausea } & \multicolumn{2}{|c|}{ Hair loss } \\
\hline & $\begin{array}{c}\text { aOR } \\
(95 \% \mathrm{CI})\end{array}$ & $P$ & $\begin{array}{c}\text { aOR } \\
(95 \% \mathrm{CI})\end{array}$ & $\boldsymbol{P}$ \\
\hline \multicolumn{5}{|l|}{ Demographics } \\
\hline Age & $\begin{array}{c}0.67 \\
(0.45-0.99)\end{array}$ & 0.05 & $\begin{array}{c}0.99 \\
(0.86-1.13)\end{array}$ & 0.84 \\
\hline Female gender & $\begin{array}{c}5.70 \\
(0.70-46.27)\end{array}$ & 0.10 & $\begin{array}{c}11.67 \\
(3.37-40.46)\end{array}$ & 0.00 \\
\hline Active smoking & $\begin{array}{c}2.31 \\
(0.45-11.87)\end{array}$ & 0.32 & $\begin{array}{c}1.28 \\
(0.45-3.61)\end{array}$ & 0.64 \\
\hline \multicolumn{5}{|l|}{ Comorbidities } \\
\hline Overweight or obesity & $\begin{array}{c}0.60 \\
(0.13-2.83)\end{array}$ & 0.52 & $\begin{array}{c}3.02 \\
(1.48-6.17)\end{array}$ & 0.00 \\
\hline Diabetes & $\begin{array}{c}25.86 \\
(3.13-213.46)\end{array}$ & 0.00 & $\begin{array}{c}1.00 \\
(0.19-5.30)\end{array}$ & 1.00 \\
\hline Asthma & $\begin{array}{c}6.19 \\
(1.26-30.44)\end{array}$ & 0.03 & $\begin{array}{c}0.86 \\
(0.26-2.86)\end{array}$ & 0.81 \\
\hline Hypertension & $\begin{array}{c}1.00 \\
(1.00-1.00)\end{array}$ & -- & $\begin{array}{c}0.90 \\
(0.30-2.70)\end{array}$ & 0.86 \\
\hline Malignancy & $\begin{array}{c}70.45 \\
(4.00-1240.52)\end{array}$ & 0.00 & $\begin{array}{c}9.64 \\
(2.16-43.10)\end{array}$ & 0.00 \\
\hline Cardiovascular disease & $\begin{array}{c}1.00 \\
(1.00-1.00)\end{array}$ & -- & $\begin{array}{c}1.00 \\
(1.00-1.00)\end{array}$ & -- \\
\hline Chronic inflammatory disease & $\begin{array}{c}4.76 \\
(0.26-87.47)\end{array}$ & 0.29 & $\begin{array}{c}0.21 \\
(0.01-3.30)\end{array}$ & 0.27 \\
\hline \multicolumn{5}{|l|}{$\begin{array}{l}\text { Timing of } \\
\text { phone survey }\end{array}$} \\
\hline$>3$ to 5 months & $\begin{array}{c}0.27 \\
(0.04-2.04)\end{array}$ & 0.21 & $\begin{array}{c}1.91 \\
(0.78-4.70)\end{array}$ & 0.16 \\
\hline$>5$ to 7 months & $\begin{array}{c}1.01 \\
(0.21-4.86)\end{array}$ & 0.99 & $\begin{array}{c}1.38 \\
(0.50-3.78)\end{array}$ & 0.53 \\
\hline$>7$ to 10 months & $\begin{array}{c}1.00 \\
\text { (reference) }\end{array}$ & -- & $\begin{array}{c}1.00 \\
\text { (reference) }\end{array}$ & -- \\
\hline
\end{tabular}

